\title{
静鋳造ステンレス鋼の凝固組織モデルを用いた三次元超音波伝搬解析の検討
}

\author{
永井 政貴*1，林 山 $^{* 1}$ ，中畑 和之*2
}

\section{Study on three-dimensional simulation of ultrasonic wave propagation in statically cast stainless steel using numerical solidified microstructure model}

\author{
Masaki NAGAI ${ }^{* 1}$, Shan LIN $^{* 1}$ and Kazuyuki NAKAHATA ${ }^{* 2}$ \\ ${ }^{{ }^{*} 1}$ Central Research Institute of Electric Power Industry \\ 2-6-1 Nagasaka, Yokosuka-shi, Kanagawa 240-0196, Japan \\ ${ }^{*}$ Graduate School of Science and Engineering, Ehime University \\ 3 Bunkyo-cho, Matsuyama, Ehime 790-8577, Japan
}

Received: 16 April 2018; Revised: 31 July 2018; Accepted: 28 October 2018

\begin{abstract}
Cast stainless steel (CASS) is widely used in primary coolant piping of nuclear power plants because of its high corrosion resistance and high strength. An in-service inspection based on ultrasonic testing (UT) has to be conducted for such weld joints on the basis of JSME Rules on Fitness-for-Service for Nuclear Power Plants. However, it is difficult to detect and estimate flaws in CASS components with high accuracy because ultrasonic waves are scattered and attenuated due to coarse grains, and anisotropic properties by grain orientations lead to ultrasonic beam distortion. In order to better understand the wave propagation behavior in the CASS, numerical simulations become useful and reasonable manners. To achieve this, it is effective to incorporate three-dimensional (3D) grain microstructures into the simulation model. If the microstructures in CASS can be made from a casting simulation, we can predict wave propagation for a more realistic situation. In this study, the cellular automaton using finite element model is introduced to imitate the grain microstructures in the CASS. Then, the constructed structure is fed into the explicit finite element analysis for 3D wave simulation. Consequently, the wave propagation using the numerical simulation show good agreement with measured wave propagation obtained by contact-scanning on the surface of CASS specimens.
\end{abstract}

Keywords : Ultrasonic testing, Cast stainless steel, Wave propagation simulation, Finite element method, Cellular automaton

\section{1. 緒言}

ステンレス鋳鋼は，耐食性および勒性が高く，原子力発電所の一次冷却材配管やポンプケーシングに用いられ ている．一次冷却材配管の溶接部は，日本機械学会が定める維持規格（日本機械学会，2012）に基づき定期的な 超音波探傷試験を実施することが要求されている. しかしながら, ステンレス鋳鋼に対する超音波探傷試験では, 粗大な結晶粒により超音波が散乱および減衰し，また音響異方性により超音波の伝搬経路が屈曲することが知ら れている，超音波の散乱および減衰は，久陥信号の SN 比を低下させ，久陥識別性の低下を招く．また，超音波 伝搬経路の屈曲は，欠陥位置の誤認や欠陥寸法の測定精度の低下に繋がる．そのため，大型の球面振動子から成 る二振動子探触子や，複数の振動子が二次元的に配列したマトリックスアレイ探触子を用い，超音波を集束させ ることで, 久陫識別性の向上を図る試みが行われている（黒住, 石田, 2004, Sakamoto et al., 2012, Lin and Shohji, 2016). また最近では，アレイ探触子の各振動子から超音波を送信するタイミング，すなわち遅延時間をステンレ ス鋳鋼の凝固組織に応じて適切に設定することで，欠陥識別性のみならず，欠陥寸法の測定精度も向上させる研 究が行われている（林，東海林，2018）。適切な遅延時間を設定するためには，凝固組織に応じて超音波がどのよ

No.18-00192 [DOI:10.1299/transjsme.18-00192], J-STAGE Advance Publication date : 9 November, 2018

*1 正員, 電力中央研究所（广240-0196 神奈川県横須賀市長坂 2-6-1）

*2 正員, 愛媛大学大学院理工学研究科（干790-8577 愛媛県松山市文京町 3)

E-mail of corresponding author: nagai@criepi.denken.or.jp 
うに伝搬するのかをまず明らかにする必要があり，そのための方法として，超音波伝搬シミュレーションが有効 である．また，超音波は材料内を三次元的に伝搬することから，その挙動は凝固組織の三次元的な分布の影響を 受ける. 既往研究（Jenson et al., 2009, Nageswaran et al., 2009, Gardahaut et al., 2015）では，マクロ試験や電子線後 方散乱回折法（Electric Backscatter Diffraction: EBSD）により断面の凝固組織を観察し，粗大結晶粒や音響異方性 の影響を考慮した超音波伝搬シミュレーションや遅延時間の最適化を行っている. しかしながら，これらの研究 では断面観察により組織の情報を得ているため，その情報は二次元に限定され，かつ実機を模擬した試験体の製 作が必要となる. 数值シミュレーションにより凝固組織の三次元的な分布を予測することができれば, 試験体を 製作することなく凝固組織により超音波伝搬がどのような影響を受けるかを把握することが可能となる．また， 上記研究では, 音線追跡 (Achenbach et al., 1982) に基づく半解析的なシミュレーションを行っており, 凝固組織 の三次元的な分布を考慮した有限要素法に基づく大規模な波動伝搬シミュレーションは行われていない.

凝固組織を予測するシミュレーション手法としては, フェーズフィールド法 (Kobayashi, 1993, Moelans et al., 2008, Steinbach, 2009）や，モンテカルロ法（Spittle and Brown, 1989, Zhu and Smith, 1992, 野上他, 2003), Cellular Automaton - Finite Element（CAFE）法（Gandin and Rappz, 1994, Gandin et al., 1999）が提案されている. フェーズ フィールド法は, デンドライトの複雑な形態予測といったミクロ凝固組織の予測に用いられているのに対し，モ ンテカルロ法と CAFE 法は, 柱状晶や等軸晶等のマクロ凝固組織の予測に用いられている（Natsume and Ohsasa, 2006).また，モンテカルロ法では確率的に結晶粒の成長を模擬しているのに対し，CAFE 法は優先成長方位を考 慮した結晶成長解析が可能である. 既往研究（Nakahata et al., 2016）では, フェーズフィールド法を用いて一方向 に成長する組織をモデル化し，超音波伝搬シミュレーションを実施している．しかしながら，同研究では比較的 大きな試験体の組織をモデル化するため, 結晶粒の成長時間やプロセスを厳密には再現しておらず，鋳造条件か ら凝固組織を予測することは困難である.

そこで本研究では, 試験体を製作することなく鋳造条件からステンレス鋳鋼の凝固組織の三次元的な分布を予 測し，予測した凝固組織をボクセルベースの陽解法有限要素法に基づいて大規模な超音波伝搬解析を実施する手 法を確立する，そのための第一段階として，シミュレーションによる凝固組織の予測が比較的容易と考えられる 静鋳造ステンレス鋼を対象とする．また，静鋳造ステンレス鋼の凝固組織を予測する方法として，実機サイズの 試験体を想定し，かつ優先成長方位を考慮した結晶粒成長が解析できる CAFE 法を採用する．本論文では，まず CAFE 法およびボクセルベースの陽解法有限要素法の概要について述べる．また，静鋳造によりステンレス鋼試 験体を製作し, 複数断面におけるマクロ組織の観察結果と CAFE 法により予測された凝固組織の比較を行う.さ らに, CAFE 法により予測した凝固組織をボクセルベースの陽解法有限要素法コードに導入し, 三次元超音波伝 搬解析を実施する. その結果を実験により観察した超音波伝搬挙動と比較することで, 提案する一連の手法によ り，実際の超音波伝搬挙動を定性的に再現できるかどうかを確認する.

\section{2. 凝固組織モデルを用いた三次元超音波伝搬解析手法}

\section{$2 \cdot 1$ CAFE 法の概要}

CAFE 法（Gandin and Rappaz, 1994）は，有限要素法（FE）を用いたマクロスケールの凝固伝熱解析と，セルラ 一オートマトン法 (CA) を用いたメゾスケールの結晶粒成長解析を連成させた解析手法である. 凝固伝熱解析で は, 凝固潜熱を考慮した非定常熱伝導解析を実施し, 得られた温度と対象とする合金の液相線温度との差から過 冷度を計算する. 結晶粒成長解析では, 解析領域を有限要素法メッシュより更に細かい CA セルに分割し, それ ぞれのセルに液相，固相，固液界面などの状態を与え，不均質核生成モデルと結晶成長モデルに従いCA セルの 状態変化を計算する. 不均質核生成モデルでは, 液相状態のセルに核を発生させる頻度を, 次式および図 1 に示 すガウス分布に基づく核生成頻度関数により確率論的に決定する. 


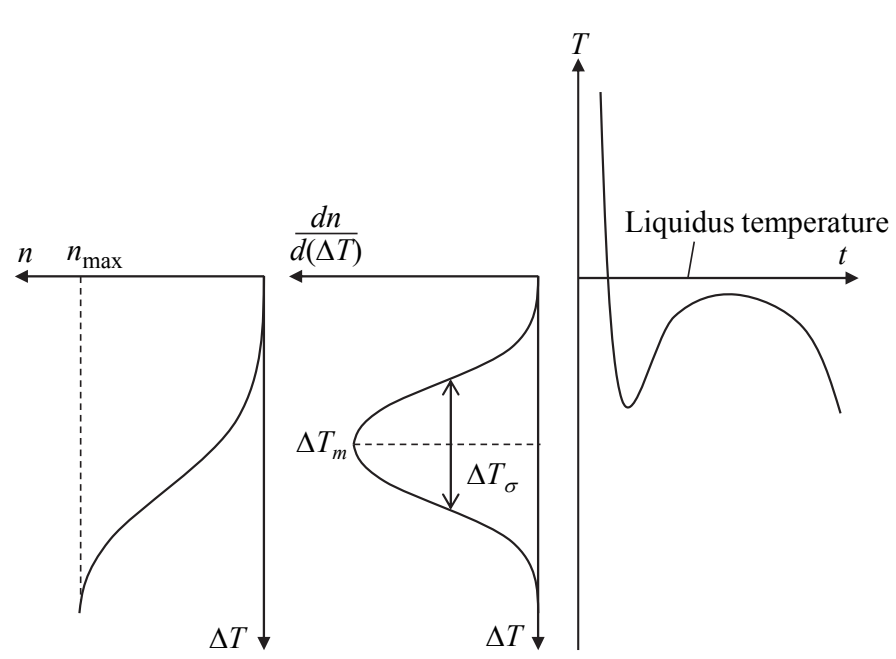

(a) Grain density (b) Nucleation distribution (c) Cooling curve

Fig. 1 Homogeneous nucleation model based on gaussian distribution.

$$
\begin{aligned}
& n(\Delta T)=\int_{T}^{T+\Delta T} \frac{d n}{d(\Delta T)} d(\Delta T) \\
& \frac{d n}{d(\Delta T)}=\frac{n_{\max }}{\Delta T_{\sigma} \sqrt{2 \pi}} \exp \left[-\frac{1}{2}\left(\frac{\Delta T-\Delta T_{m}}{\Delta T_{\sigma}}\right)\right]
\end{aligned}
$$

ここで， $n, T$ および $\Delta T$ はそれぞれ核密度，温度および過冷度， $n_{\max }, \Delta T_{m}$ および $\Delta T_{\sigma}$ はそれぞれ最大核密度，平 均過冷度および過冷度の標準偏差を表す.式（2）で表せる核生成頻度関数は，鋳型表面および溶湯中でそれぞれ 定義される．また，生成した核にはデンドライトの優先成長方位がランダムに割り付けられる.

不均質核生成モデルにより発生した核は，デンドライト成長動力学（Kurz et al., 1986）に基づく結晶成長モデ ルに従い成長する．簡単のため，図 2 に示す二次元問題を考える.同図において，セル間隔は $L$ と，ある時間 $t$ に核生成する CA セルの中心を $v$ ，隣接する 4 つの CA セルの中心をそれぞれ $\mu_{1}, \mu_{2}, \mu_{3}$ および $\mu_{4}$ と定義する. 生 成したデンドライトをその優先成長方位[10]および[01]がそれぞれ $x$ 軸と角度 $\theta$ よび $\theta+\pi / 2$ を成す対角線を有す る四角形として定義する. CA セルの温度分布は局所的に一様であるとし，デンドライトの優先成長方位を表す 四角形のそれぞれの頂点の $\Delta t$ 間の成長距離 $L_{v, j}^{t}(j=1 \sim 4)$ は次式で表せる.

$$
{ }^{*} L_{v, j}^{t}=\int_{t}^{t+\Delta t} v\left(\Delta T_{v}^{t}\right) d t
$$

ここで，v( $\left(\Delta T_{v}^{t}\right)$ は KGT モデル（Kurz et al., 1986）に基づくデンドライト先端の成長速度を示し，次式の形式で過 冷度 $\Delta T$ の関数として用いられることが多い.

$$
v\left(\Delta T_{v}^{t}\right)=a_{2}\left(\Delta T_{v}^{t}\right)^{2}+a_{3}\left(\Delta T_{v}^{t}\right)^{3}
$$


ここで, 係数 $a_{2}$ および $a_{3}$ は合金の種類により決定される. デンドライトの(11)面の成長距離 $L_{v, j}^{t}$ は次式で表せる.

$$
L_{v, j}^{t}={ }^{*} L_{v, j}^{t} / \sqrt{2}
$$

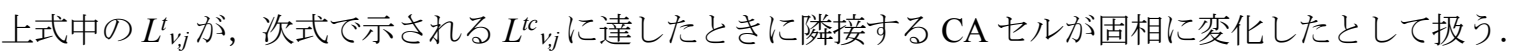

$$
L_{v, j}^{t_{c}}=\frac{L}{\sqrt{2}}(\cos \theta+|\sin \theta|)
$$

$\mathrm{CA}$ 法における核生成および核の結晶成長の結果として変化した固相率を有限要素法の凝固伝熱解析に反映させ ることで, 有限要素法と CA 法の連成が達成される。なお，CA 法による結晶粒成長解析の結果を有限要素法解 析に反映させない弱連成解析手法も提案されており（Gandin et al., 1999），本論文ではこの弱連成解析手法を採用 した.

\section{$2 \cdot 2$ ボクセルベースの陽解法有限要素法}

CAFE 法により予測した凝固組織は, ボクセル要素を用いた陽解法有限要素法に導入し, 超音波伝搬シミュレ ーションを実施する．以下では，その概要について説明する.

直交座標系 $\boldsymbol{x}=\left(x_{1}, x_{2}, x_{3}\right)$ において，固体の変位 $\boldsymbol{u}(\boldsymbol{x}, t)=\left(u_{1}, u_{2}, u_{3}\right)$ に関する運動方程式は次式で表せる.

$$
\frac{\partial \sigma_{i j}(\boldsymbol{x}, t)}{\partial x_{j}}=\rho(\boldsymbol{x}) \ddot{u}_{i}(\boldsymbol{x}, t), \quad(i=1,2,3)
$$

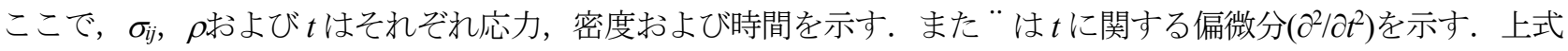

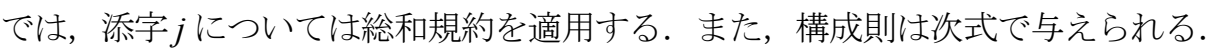

$$
\sigma_{i j}(\boldsymbol{x}, t)=C_{i j k l}\left[\frac{1}{2}\left\{\frac{\partial u_{k}(\boldsymbol{x}, t)}{\partial x_{l}}+\frac{\partial u_{l}(\boldsymbol{x}, t)}{\partial x_{k}}\right\}\right], \quad(i, j=1,2,3)
$$

ここで， $C_{i j k l}$ は弾性スティフネスを示し， Voigt 表記を用いて次式で表せる.

$$
\left[\begin{array}{l}
\sigma_{11} \\
\sigma_{22} \\
\sigma_{33} \\
\sigma_{23} \\
\sigma_{13} \\
\sigma_{12}
\end{array}\right]=\left[\begin{array}{cccccc}
C_{11} & C_{12} & C_{13} & C_{14} & C_{15} & C_{16} \\
& C_{22} & C_{23} & C_{24} & C_{25} & C_{26} \\
& & C_{33} & C_{34} & C_{35} & C_{36} \\
& & & C_{44} & C_{45} & C_{46} \\
& S y m . & & & C_{55} & C_{56} \\
& & & & & C_{66}
\end{array}\right]\left[\begin{array}{c}
\partial u_{1} / \partial x_{1} \\
\partial u_{2} / \partial x_{2} \\
\partial u_{3} / \partial x_{3} \\
\partial u_{2} / \partial x_{3}+\partial u_{3} / \partial x_{2} \\
\partial u_{1} / \partial x_{3}+\partial u_{3} / \partial x_{1} \\
\partial u_{1} / \partial x_{2}+\partial u_{2} / \partial x_{1}
\end{array}\right]
$$


重み付き残差法を用いて，式（7）を空間に対して離散化する. 重み関数の任意性から, 次の要素剛性方程式が 得られる.

$$
\boldsymbol{M}_{j} \ddot{\boldsymbol{d}}_{j}+\boldsymbol{K}_{j} \boldsymbol{d}_{j}=\boldsymbol{f}_{j}
$$

ここで, $\boldsymbol{M}_{j}, \boldsymbol{K}_{j}, \boldsymbol{d}_{j}$ および $\boldsymbol{f}_{j}$ はそれぞれ有限要素 $\boldsymbol{j}$ の質量マトリックス, 剛性マトリックス, 節点変位ベクトルお よび節点力ベクトルを示す. また，要素 $j$ は一辺が $\Delta x$ の立方体とする. 式（10）を全要素数分組み合わせること で，次式で表せる解析領域全体の運動方程式が得られる.

$$
M \ddot{d}+K d=f
$$

時間軸の離散化については，現在の時刻ステップを $k$ とし，その時刻から $\Delta t$ 前後の時刻に対応するステップを $k-1$ および $k+1$ とすれば，現在の時刻の加速度 $\ddot{\boldsymbol{d}}^{k}$ は中心差分式を用いて次式で表せる.

$$
\ddot{\boldsymbol{d}}^{k} \approx \frac{1}{\Delta t^{2}}\left(\boldsymbol{d}^{k+1}-2 \boldsymbol{d}^{k}+\boldsymbol{d}^{k-1}\right)
$$

となる．式（12）を式（11）に代入すると,

$$
\boldsymbol{M d}^{k+1}=\left(2 \boldsymbol{M}-\Delta t^{2} \boldsymbol{K}\right) \boldsymbol{d}^{k}+\Delta t^{2} \boldsymbol{f}^{k}-\boldsymbol{M d}^{k-1}
$$

が得られる. 上式は，現在の時刻ステップ $k$ における值と $\Delta t$ 前のステップ $k-1$ の值を用いて, $\Delta t$ 後のステップ $k$ +1 における変位が求められることを意味している. 式（13）の質量マトリックス $\boldsymbol{M}$ の対角化を行ったものを集 中質量マトリックス $\tilde{\boldsymbol{M}}$ と呼ぶ. このとき, 次式で示すように, 節点変位ベクトル $\boldsymbol{d}$ の成分が独立となるため陽 的な解法となり, 単純な代入計算で変位が逐次求められる. ただし, この場合 Coulant 条件を満足するように $\Delta t$ を設定する必要がある.

$$
\boldsymbol{d}^{k+1}=\left(2 \boldsymbol{I}-\Delta t^{2} \tilde{\boldsymbol{M}}^{-1} \boldsymbol{K}\right) \boldsymbol{d}^{k}+\Delta t^{2} \tilde{\boldsymbol{M}}^{-1} \boldsymbol{f}^{k}-\boldsymbol{d}^{k-1}
$$

CAFE 法では, 立方体状の CA セルに, 対応する結晶粒の優先成長方位[001]をオイラー角として出力するので, これを各要素の弾性スティフネス $C_{i j k l}$ に反映することで, 凝固組織を有限要素法に導入することができる. また, 本解析法ではすべて同サイズの要素（一辺が $\Delta x$ のボクセル要素）を用いているので, CAFE 法の CA セルの等倍 または整数分の一のサイズにボクセル要素のサイズを合わせることによって, CAFE 法から得られた結晶粒の形 状データをそのまま FEM に取り込むことができる. 式（14）の計算で，全ての要素で全体剛性マトリックス $\boldsymbol{K}$

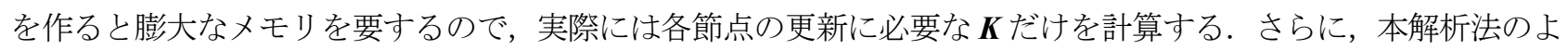
うに要素形状が同一である場合には, 結晶粒の数だけ $\boldsymbol{K}$ を事前に計算し, 参照テーブルとしてメモリに保存寸れ ば，計算効率は格段に向上寸る，三次元計算の場合では，要素数が相当多くなるが，ここでは計算対象を副領域 に分割して，Flat MPI 並列計算（Nakahata et al., 2016）を導入して高速化を図っている. 
Table 1 Casting conditions of CASS specimen.

\begin{tabular}{|c|c|c|c|c|c|c|c|c|c|c|}
\hline Mold material & Ceramic beads & & Table 2 & Chen & al con & osition & CASS & pecimen & $(w t \%)$. & \\
\hline Mold temperature & $18.1^{\circ} \mathrm{C}$ & $\mathrm{C}$ & $\mathrm{Si}$ & $\mathrm{Mn}$ & $\mathrm{P}$ & $\mathrm{S}$ & $\mathrm{Ni}$ & $\mathrm{Cr}$ & Mo & $\mathrm{Co}$ \\
\hline Casting temperature & $1525^{\circ} \mathrm{C}$ & 0.07 & 0.95 & 0.80 & 0.01 & 0.008 & 10.96 & 19.06 & 2.21 & 0.00 \\
\hline
\end{tabular}

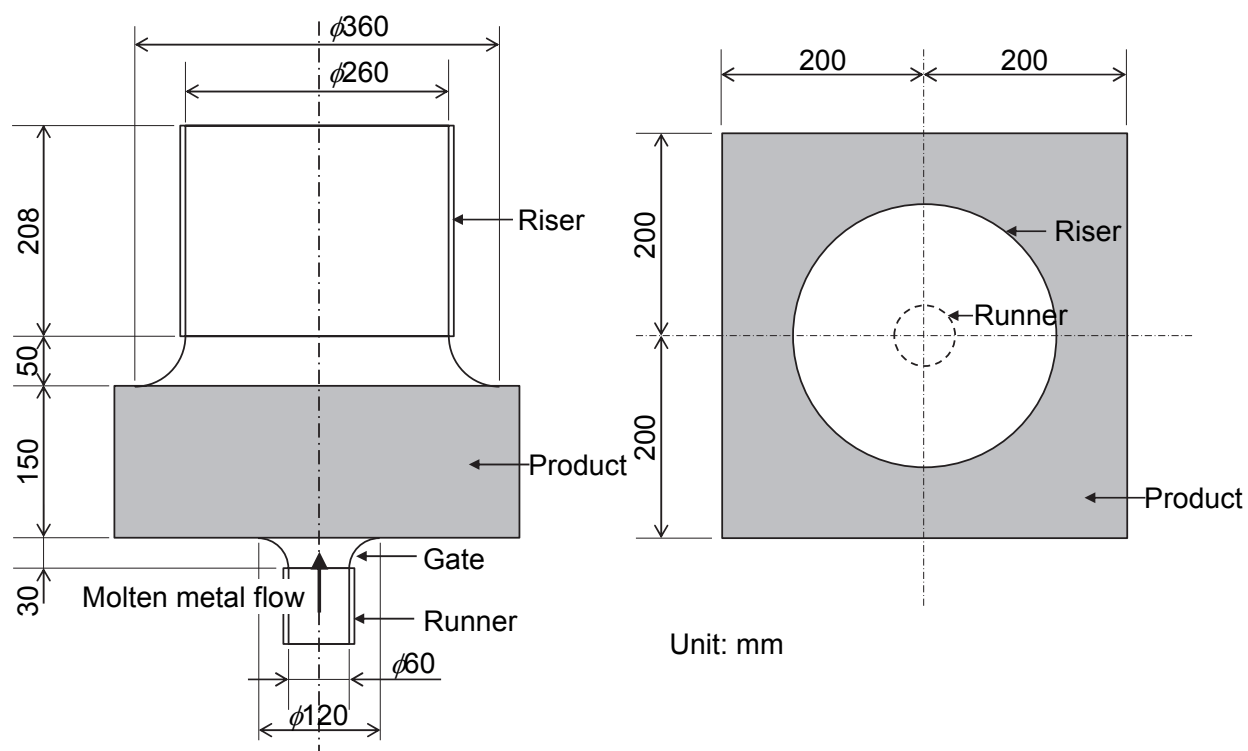

Fig. 3 Dimensions of mold.

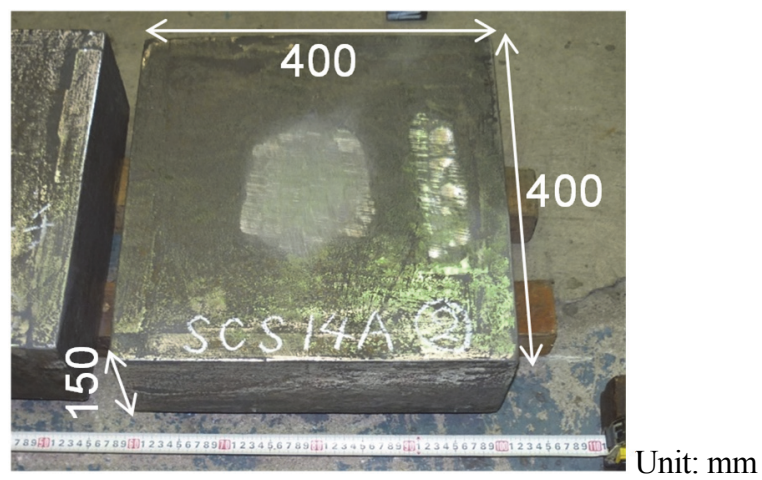

Fig. 4 Overview of cast stainless steel specimen.

\section{3. マクロ凝固組織の予測}

\section{$3 \cdot 1$ 静鋳造ステンレス鋼試験体の製作}

静鋳造により二相ステンレス鋳鋼（JIS 規格 SCS14A）を製作した. 鋳型寸法および鋳造条件をそれぞれ図 3 お よび表 1 に示す．また，試験体の外観および化学成分をそれぞれ図 4 および表 2 に示す，試験体は切断し，表面 を塩化第二鉄および塩酸の水溶液で腐食し, マクロ試験を実施した.

\section{$3 \cdot 2$ CAFE 法による凝固組織の予測}

本節では, 3.1 節で製作した静鋳造ステンレス鋼の試験体について, CAFE 法を用いて鋳造条件からその凝固組 織の予測を行った. CAFE 解析には, 有限要素法に基づいて鋳造シミュレーションが行える商用ソフトウェア ProCAST 2015.0 (米澤, 2014）を用いた. 同ソフトウェアにはCAFEによる凝固組織予測機能が実装されており, 


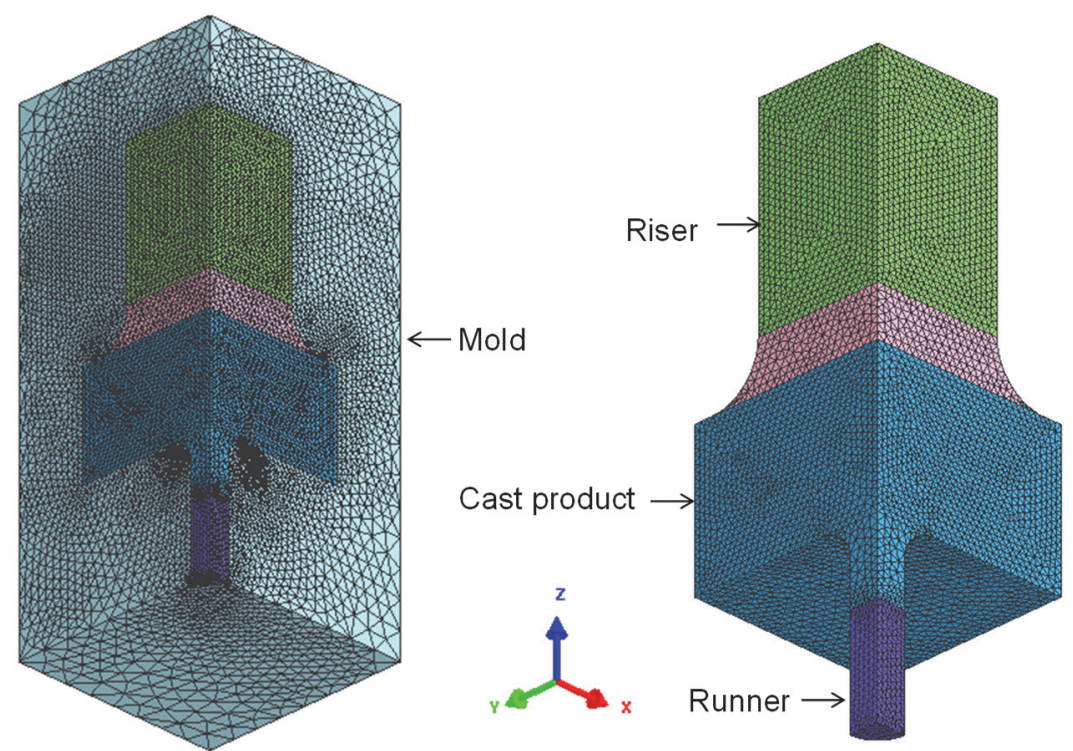

Fig. 5 Mesh used in finite element calculation of CAFE method.

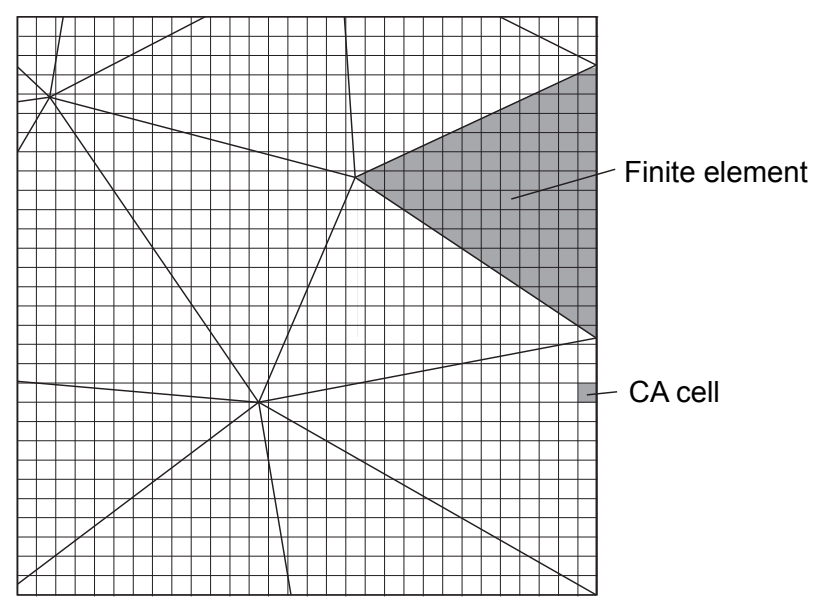

Fig. 6 A typical geometrical relationship between finite elements and CA cells.

各結晶粒の優先成長方位[001]をオイラー角として出力する機能を備えている.また, 有限要素法解析では, 溶湯 の流動も解析できる機能を有している．後述するように 3.1 節で製作した試験体の凝固組織は軸対称な分布を示 していたため, 本研究の解析では, 1/4 モデルを対象領域とする.

有限要素法解析は, 解析領域を $7 \mathrm{~mm}$ 程度の四面体要素を用いてデロー二分割した．総要素数は 340,726 で, 要素分割図を図 5 に示寸，一般的な鋳造工程では温度分布の極端な変動は生じないため，この程度の有限要素分 割で十分と考えられる. 物性值は, 表 2 に示した化学成分から ProCAST に実装された熱力学データベース（Cao et al., 2009）を用いて計算される. ただし，表 2 に示した化学成分のうち，Co，P，Sについては值が小さくデー タベースの適用範囲に満たないため, これらの 3 元素は除いて計算した。 その結果, 液相線温度および固相線温 度はそれぞれ $1450^{\circ} \mathrm{Cおよび} 1401^{\circ} \mathrm{C}$ とった. 境界条件は, 表 1 に従い鋳型と溶湯の初期温度をそれぞれ $18.1^{\circ} \mathrm{C}$ と $1525^{\circ} \mathrm{C}$ とた。 また, 溶湯と鋳型の境界の熱伝達係数は $300 \mathrm{~W} /\left(\mathrm{m}^{2} \mathrm{~K}\right)$ とし, 溶湯が充填される前の鋳型内部は真 空と仮定して溶湯液面の熱伝達係数は $0 \mathrm{~W} /\left(\mathrm{m}^{2} \mathrm{~K}\right)$, すなわち断熱条件とした. 主な解析条件を表 3 に示す.

$\mathrm{CA}$ 解析では，解析領域を一辺 $0.5 \mathrm{~mm}$ の立方体セルに分割して解析を行った．総セル数は 55,527,499 個で，四 面体有限要素と CA セルの典型的な幾何学的な関係を図 6 に示す. 3.1 節で製作した試験体の結晶粒の最小サイズ が $0.3 \mathrm{~mm}$ 程度であったこと, および計算時間を勘案して CA セルサイズを $0.5 \mathrm{~mm}$ と設定した. KGT モデルの係 数 $a_{2}, a_{3}$ を表 4 に示寸が, これらの值も表 2 に示した化学成分から ProCAST に実装された熱力学データベース 
Table 3 Conditions of finite element calculation of CAFE method.

\begin{tabular}{ll} 
Solidus temperature & $1401^{\circ} \mathrm{C}$ \\
Liquidus temperature & $1450^{\circ} \mathrm{C}$ \\
Heat transfer coefficient between SCS14A and Mold & $300 \mathrm{~W} /\left(\mathrm{m}^{2} \mathrm{~K}\right)$ \\
Heat transfer coefficient between Riser and Mold & $35 \mathrm{~W} /\left(\mathrm{m}^{2} \mathrm{~K}\right)$ \\
Heat transfer coefficient between Mold and Air & $80 \mathrm{~W} /\left(\mathrm{m}^{2} \mathrm{~K}\right)$ \\
\hline
\end{tabular}

Table 4 Coefficients used in KGT model.

$a_{2} \quad 2.53 \times 10^{-7} \mathrm{~mm} /\left(\mathrm{s} \mathrm{K}^{2}\right)$

$a_{3} \quad 6.71 \times 10^{-8} \mathrm{~mm} /\left(\mathrm{s} \mathrm{K}^{3}\right)$

Table 5 Parameters used in homogeneous nucleation model.

\begin{tabular}{cccccc}
\hline & Volume nucleation & \multicolumn{3}{c}{ Surface nucleation } \\
$\Delta T_{m}$ & $\Delta T_{\sigma}$ & $n_{\max }$ & $\Delta T_{m}$ & $\Delta T_{\sigma}$ & $n_{\max }$ \\
\hline $12^{\circ} \mathrm{C}$ & $1{ }^{\circ} \mathrm{C}$ & $1 \times 10^{9} \mathrm{~m}^{-3}$ & $6^{\circ} \mathrm{C}$ & $1{ }^{\circ} \mathrm{C}$ & $1.2 \times 10^{6} \mathrm{~m}^{-2}$ \\
\hline
\end{tabular}

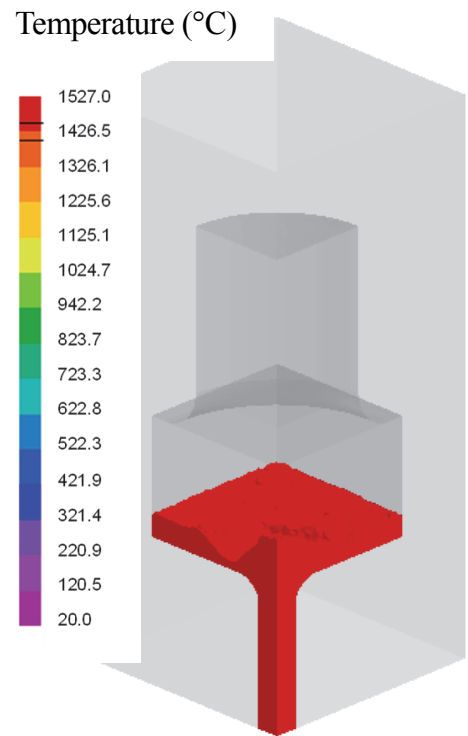

(a) $2 \mathrm{~s}$

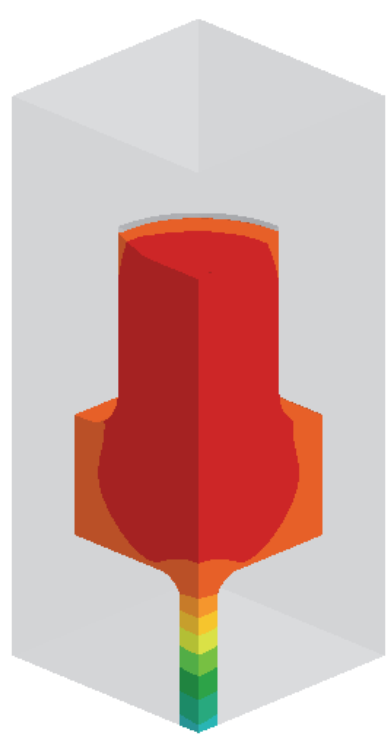

(e) $2378 \mathrm{~s}$

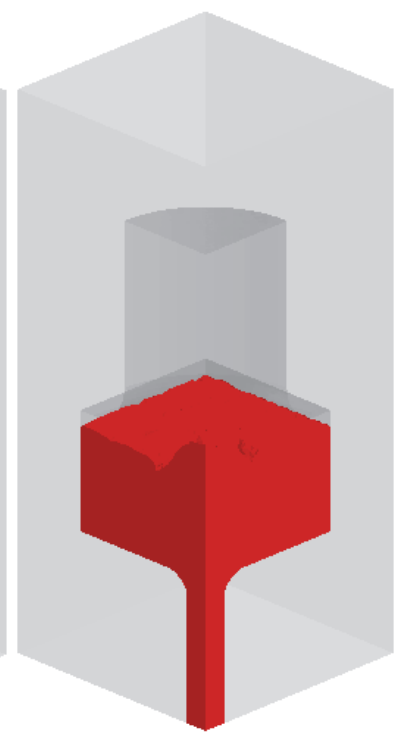

(b) $10 \mathrm{~s}$

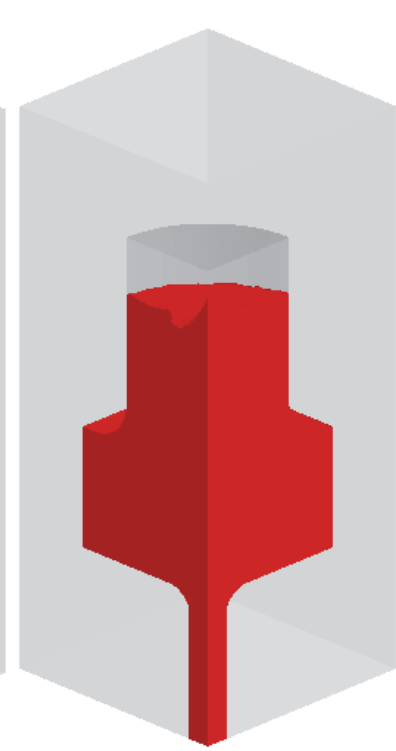

(c) $16 \mathrm{~s}$

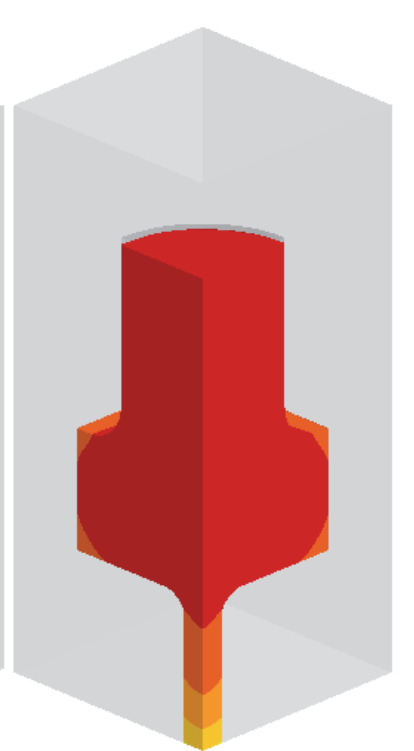

(d) $578 \mathrm{~s}$

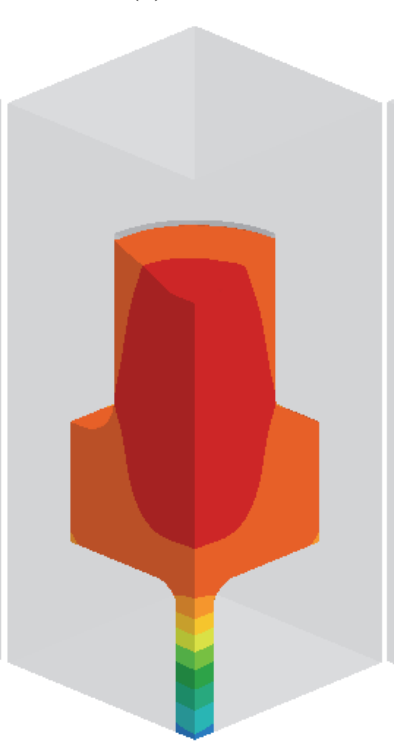

(f) $4178 \mathrm{~s}$

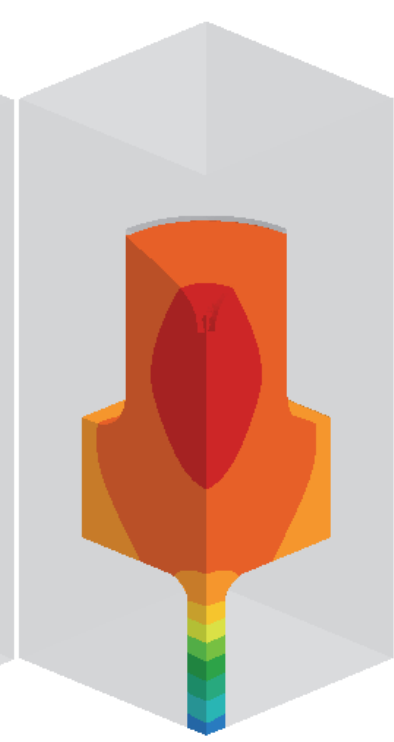

(g) $5978 \mathrm{~s}$

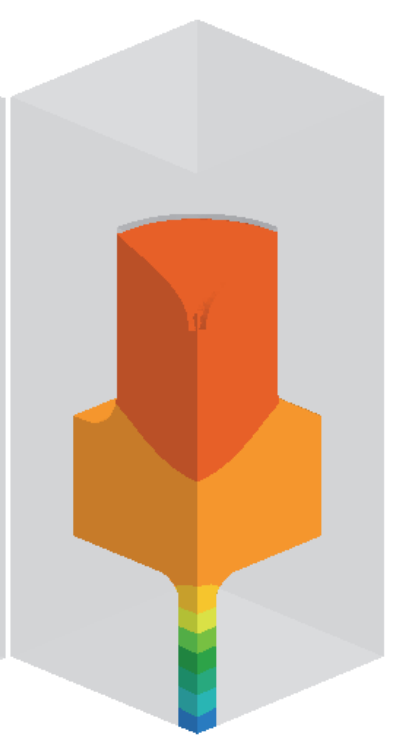

(h) $8378 \mathrm{~s}$

Fig. 7 Temperature distributions obtained by finite element calculation of CAFE method. Mold is being filled with molten metal from bottom and then metal is cooled gradually. 
Table 6 Statistical distribution of grain area.

\begin{tabular}{lrrrr}
\hline & \multicolumn{2}{c}{ Vertical cross-section } & \multicolumn{2}{c}{ Horizontal cross-section } \\
& Macroscopic test result & CAFE result & Macroscopic test result & CAFE result \\
\hline Number of grains & 308 & 367 & 648 & 1187 \\
Mean of grain area & $74.8 \mathrm{~mm}^{2}$ & $72.5 \mathrm{~mm}^{2}$ & $47.7 \mathrm{~mm}^{2}$ & $27.2 \mathrm{~mm}^{2}$ \\
Standard deviation of grain area & $142.0 \mathrm{~mm}^{2}$ & $139.9 \mathrm{~mm}^{2}$ & $87.5 \mathrm{~mm}^{2}$ & $41.2 \mathrm{~mm}^{2}$ \\
Maximum of grain area & $961.4 \mathrm{~mm}^{2}$ & $1113 \mathrm{~mm}^{2}$ & $820.3 \mathrm{~mm}^{2}$ & $608.5 \mathrm{~mm}^{2}$ \\
Minimum of grain area & $0.12 \mathrm{~mm}^{2}$ & $0.25 \mathrm{~mm}^{2}$ & $0.10 \mathrm{~mm}^{2}$ & $0.25 \mathrm{~mm}^{2}$ \\
\hline
\end{tabular}

を用いて計算される. また, CA 解析に用いた不均質核生成頻度関数のパラメーターを表 5 に示寸. 製作した試 験体では鋳型表面から結晶粒が成長していたため，鋳型表面で核生成が生じ易いように，鋳型表面の $\Delta T_{m} と \Delta T_{\sigma}$ は先行研究（Gandin and Rappz, 1994）を参考に決定し，溶湯中の $\Delta T_{m}$ は鋳型表面の值の倍とした. 図 7 に有限要 素法解析結果を示す. 同図より，溶湯が鋳型下方から逐次充填されていき，充填後は周囲から徐々に冷却されて いる様子が確認できる.

\section{$3 \cdot 3$ 凝固組織の比較}

図 8 に, 静鋳造ステンレス鋼試験体の垂直断面（図 8(a)）と水平断面（図 8(b)）のマクロ組織観察結果（図 8 (c) および(e)）と，それぞれの断面に対応するCAFE 解析結果（図 8 (d)および(f)）を示す．同図のマクロ観察結果画 像では, 各結晶粒の粒界を明確化する画像処理を行っている. 図 8 (c)および(d)に示す垂直断面から CAFEにより 鋳型下方および側面から鋳型上面に向かって柱状晶が成長している様相が模擬できている．また，同図の(e)およ び(f)に示す水平断面から鋳型中心軸に関して対称な結晶粒成長も模擬できている．表 6 にマクロ組織観察および CAFE 解析から得られる各結晶粒の面積について統計的に比較したものを示す．なお，静鋳造品の鋳型表面近傍 は組織が安定しておらず, 製品にも用いられないことから, 図 7 に示すように鋳型境界から $10 \mathrm{~mm}$ 離した破線で 囲った領域の結晶粒について比較を行った，表 6 より，垂直断面に関しては，観察結果による結晶粒数，粒面積 の平均值および標準偏差がそれぞれ 308 個, $74.8 \mathrm{~mm}^{2}$ および $142.0 \mathrm{~mm}^{2}$ であるのに対し, 解析結果によるそれら は 367 個, $72.5 \mathrm{~mm}^{2}$ および $139.9 \mathrm{~mm}^{2}$ と，両者が概ね一致している，一方，水平断面に関しては，観察結果によ る結晶粒数, 粒面積の平均值および標準偏差がそれぞれ 648 個, $47.7 \mathrm{~mm}^{2}$ および $87.5 \mathrm{~mm}^{2}$ であるのに対し, 解析 結果によるそれらは 1187 個, $27.2 \mathrm{~mm}^{2}$ および $41.2 \mathrm{~mm}^{2}$ と, 両者がほとんど一致していない. 水平断面における CAFE 解析結果では, 結晶粒面積の平均值が観察結果の $1 / 2$ 程度となっており, 結晶粒数は観察結果の 2 倍近く になっている. 水平断面に関する解析結果が観察結果と異なった原因としては, CAFE 解析が実現象を完全に模 擬していないために生じたと考えられる. 特に，マクロスケールの有限要素法解析により得られた温度分布が実 際と異なっている可能性，およびメゾスケールのセルラーオートマトン法解析における核生成頻度関数のパラメ ーター設定が適切でない可能性の二つが考えられ，これらを解決することで凝固組織の予測精度を向上させるこ とが可能と考えられる.

\section{4. 凝固組織を考慮した超音波伝搬シミュレーション}

\section{$4 \cdot 1$ 超音波伝搬挙動の観察}

図 9 に示寸超音波可視化システム（林他，2007）を用いて，静鋳造ステンレス鋼の超音波伝搬挙動を実験的に 観察した．可視化にあたっては，固体の直交した面の一方に送信用探触子を配置し，他方の面に受信用探触子を 二次元的に走査することによって波形データを集録する，具体的には，受信用探触子を走査するたびに，送信用 探触子から超音波を送信し，その波形を受信用探触子において記録する。この操作を全ての走查点において繰り 返し, 最終的に取得した波形データの各走查点における波形の振幅を輝度值として二次元表示寸ることで，固体 内の超音波の波面を近似的に表現できる. 図 9 に示寸システムは, 超音波の送受信のためのパルサーレシーバー, 波形データを表示するためのオシロスコープ, 受信用探触子を操作するための二軸移動ステージとステージコン 


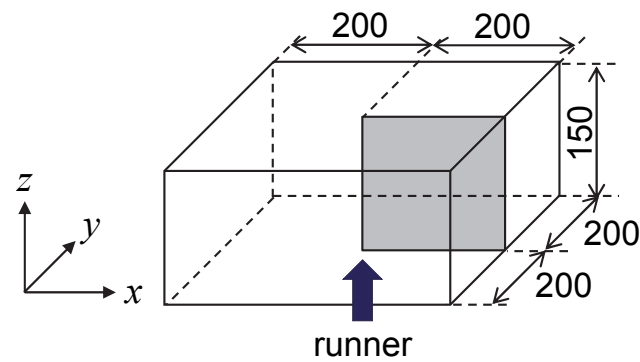

(a) Vertical cross-section

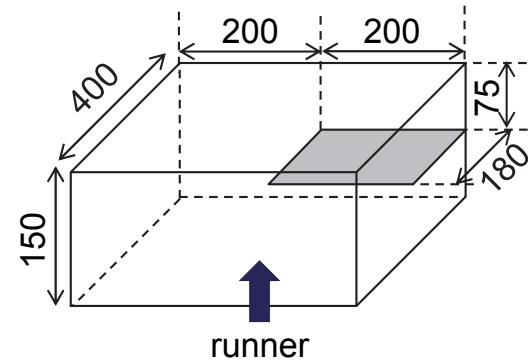

Unit: $\mathrm{mm}$

(b) Horizontal cross-section

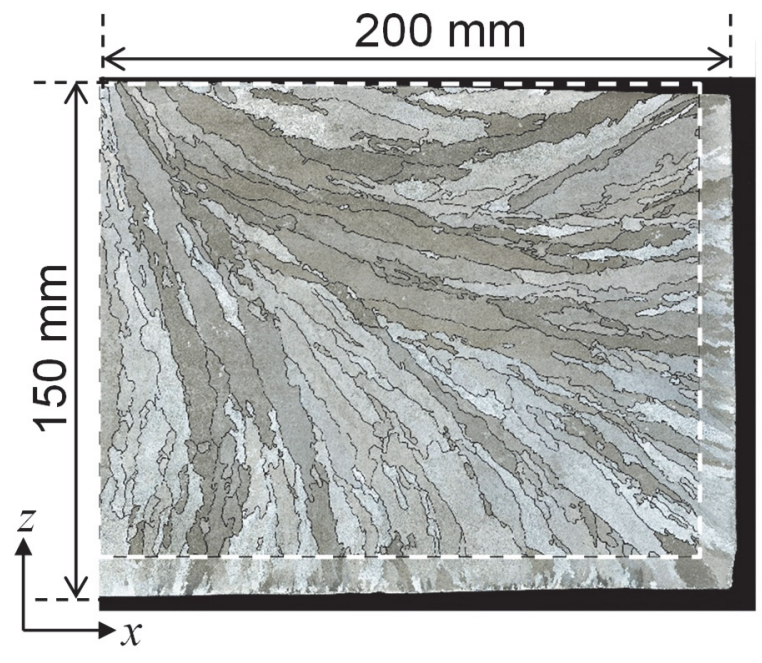

(c) Macroscopic test result of vertical cross-section

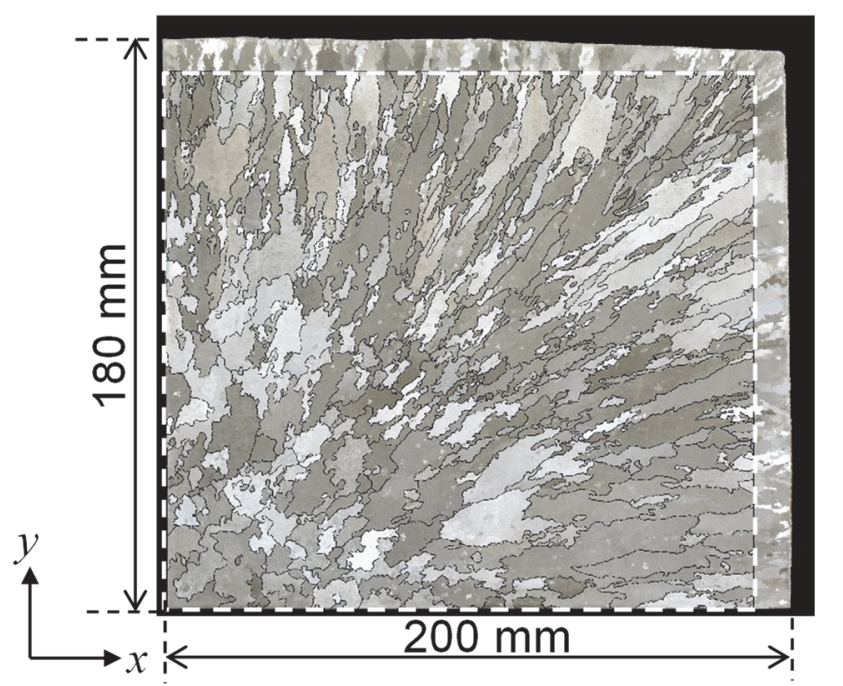

(e) Macroscopic test result of horizontal cross-section

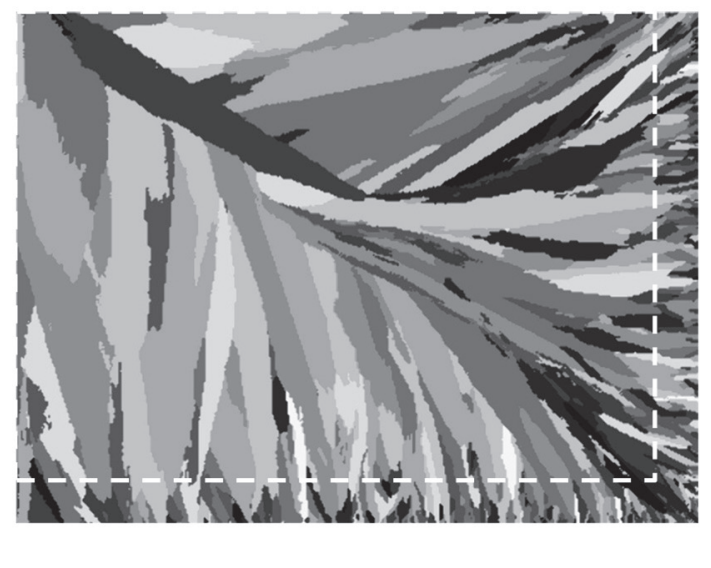

(d) CAFE result of vertical cross-section

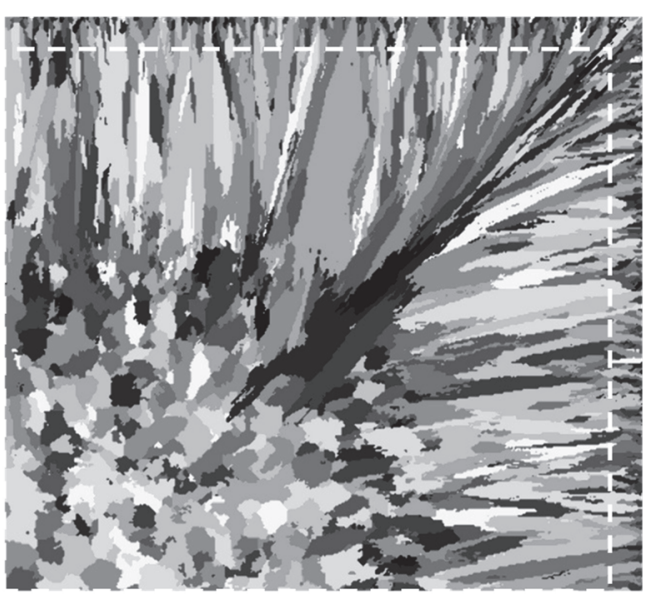

(f) CAFE result of horizontal cross-section

Fig. 8 Comparison between macroscopic test result and CAFE results.

Feature that columnar grains grew from sides and bottom to top of mold is predicted by CAFE method.

トローラー，ならびに波形データの集録，移動ステージの制御，超音波の波面を表示寸るためのコンピューター から構成されている，送信用探触子には中心周波数 $1 \mathrm{MHz}$ ，振動子径 $25.4 \mathrm{~mm}$ の垂直探触子を用いた．また，受 信用探触子には中心周波数 $1 \mathrm{MHz}$, 振動子径 $1 \mathrm{~mm}$ の垂直探触子を用い, 測定範囲を $0.2 \mathrm{~mm}$ ピッチで走査させた. 
ここで，受信には垂直探触子を用いているが，探触子を試験体に強く押し付けていること，振動子径が $1 \mathrm{~mm}$ 小さく点音源に近いと仮定できることから，可視化される波面は面外変位だけでなく面内変位も含まれていると 考えられる. 観察する対象は垂直断面と水平断面とし, それぞれの観察した試験体の部位と測定範囲を図 10 およ び 11 に示す. 図 10 (a)の赤線で示した部位は，3.1 節において製作した試験体のうち垂直断面に対応する部位を 示し, 同図(b)の赤線で示寸部位は(a)で示した部位から波動観察のために切り出した部位を示す. 図 10 (c) (e)は, 切り出した部位のうち超音波伝搬挙動を観察する領域を示寸.ここで, 図 10 に示す垂直断面は, 図 8 (c)で観察 した断面とは異なる断面だが, 結晶粒は中心軸に対して軸対称な分布を示しているため, 図 10 に示す別断面にお いても結晶粒の分布傾向はほとんど変わらないと仮定した. 図 11 (a)の赤線で示した部位は，水平断面に対応す る部位を示し, 同図(b)の赤線で示寸部位は(a)で示した部位から波動観察のために切り出した部位を示す. 図 11 (b) に示寸水平断面は図 $8(\mathrm{e})$ に示した断面に対応する.測定範囲は送信探触子を設置した面から $15 \mathrm{~mm}$ 離れた幅方向

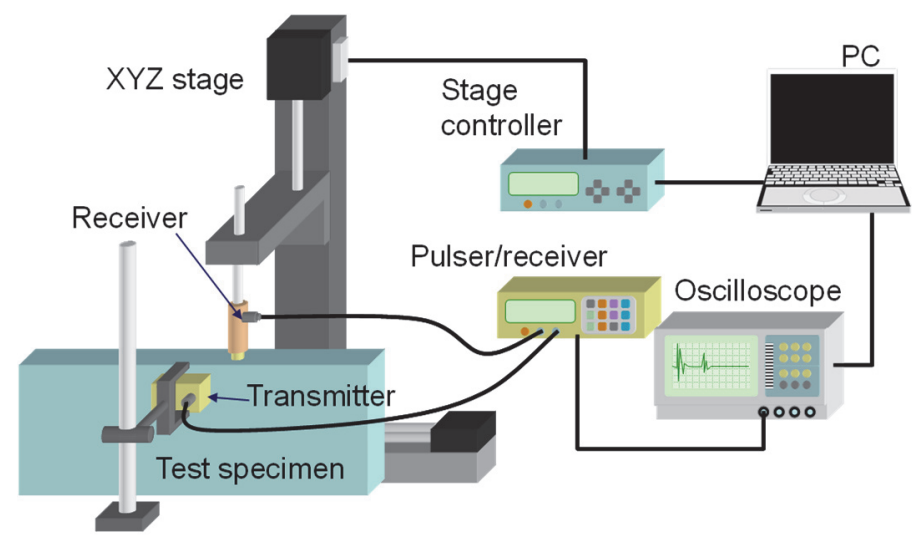

Fig. 9 Experimental visualization system for ultrasonic wave propagation behavior.

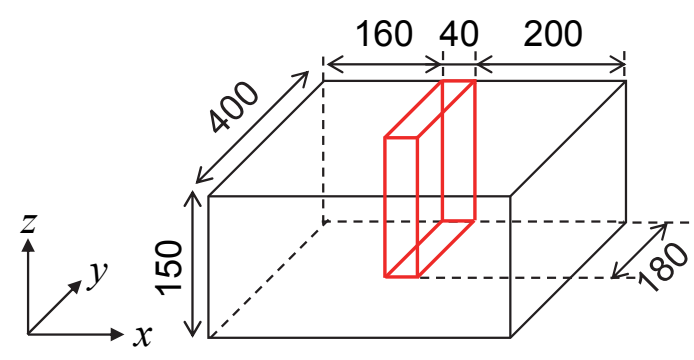

(a) Vertical cross-section block cut out of CASS specimen.

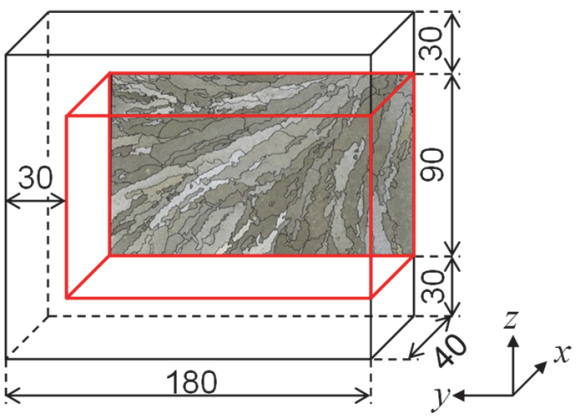

Unit: $\mathrm{mm}$

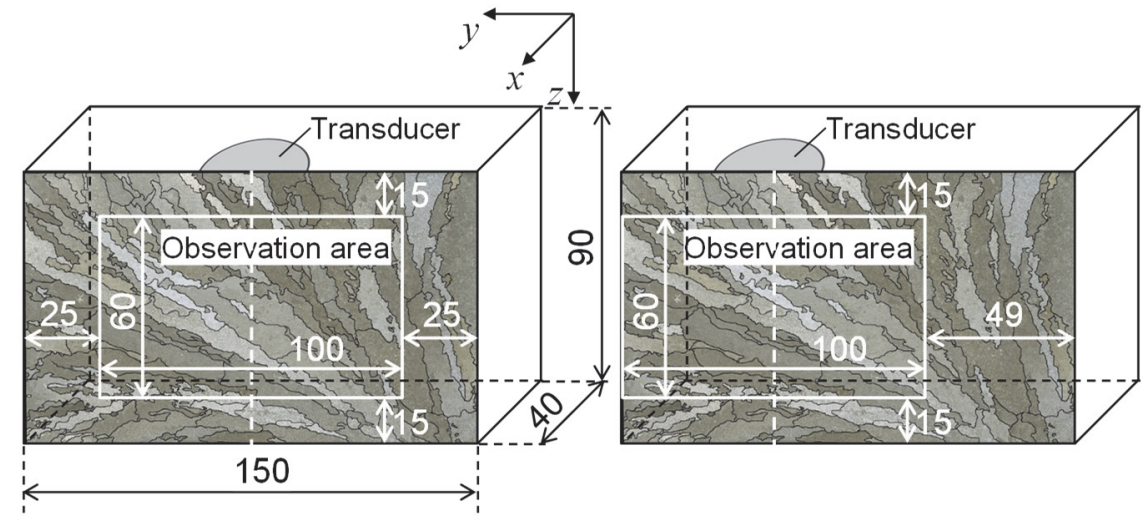

(c) Incident position 1

(d) Incident position 2

Fig. 10 Observation areas on vertical cross-section. 
に $100 \mathrm{~mm}$ ，板厚方向に $60 \mathrm{~mm}$ の長方形領域とし，探触子の中心と測定領域の中心を合わせた．また，同じ断面 においても超音波の入射位置による伝搬挙動の違いを調べるために，図 10 および 11 に示すように，垂直断面お よび水平断面に関してそれぞれ 2 か所から超音波を入射させた．観察結果は次節における有限要素法に基づく超 音波伝搬シミュレーション結果と併せて示す.
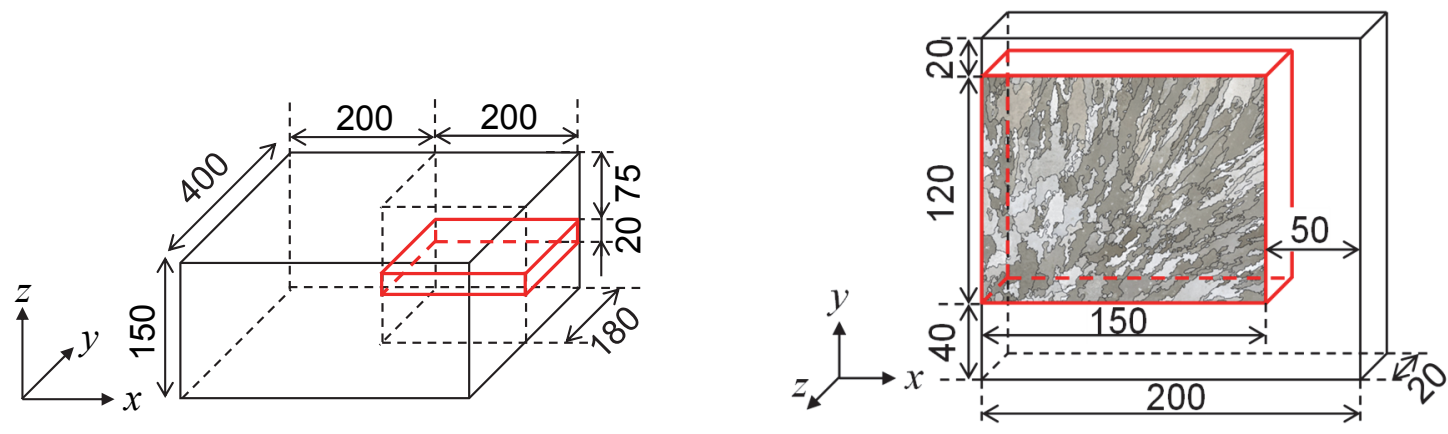

Unit: mm

(a) Horizontal cross-section block cut out of CASS specimen. $\quad$ (b) Observation specimen cut out of horizontal cross-section block.

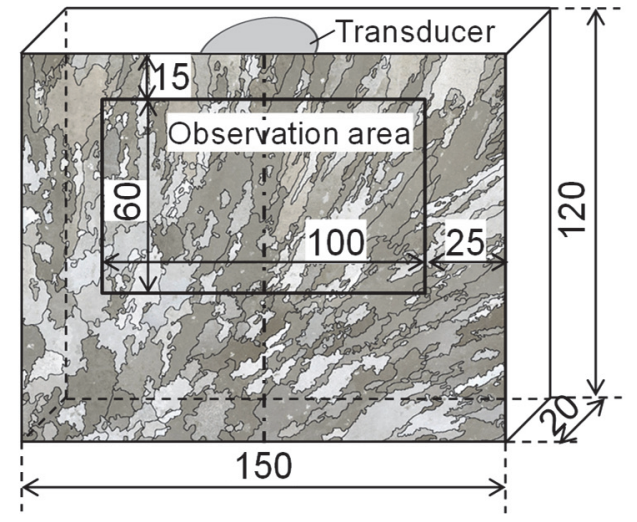

(c) Incident position 3

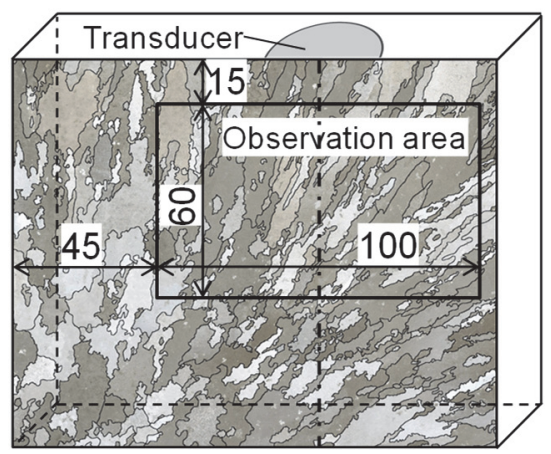

(d) Incident position 4

Fig. 11 Observation areas on horizontal cross-section.

\section{$4 \cdot 2$ 有限要素法に基づく超音波伝搬シミュレーション}

3.3 節で示した CAFE 解析により予測された凝固組織に対して，有限要素法による超音波伝搬シミュレーショ ンを行った. シミュレーションはマクロ組織観察を行った断面のみをモデル化した平面ひずみ近似による二次元 解析と, 面外方向の結晶粒分布も考慮した三次元解析の 2 通りについて行った. 二次元解析および三次元解析共 に著者らの一人（Nakahata et al., 2016）が開発したボクセルベースの陽解法有限要素法コードを用いた. 入射波は 図 12 に波形を示寸中心周波数 $1 \mathrm{MHz}$ の波とし, 4.1 節で示した超音波可視化システムの送信探触子を配置した位 置に表面力として与えた. 前述したように, CAFE 法では CA セルに結晶粒の優先成長方位[001]をオイラー角と して出力するので, 出力されたオイラー角を用いて CA セルに対応する有限要素の弾性スティフネスを座標変換 することで，結晶粒方位を有限要素法に導入した．また，結晶粒は全て SCS14A 相当材である SUS316 単結晶と して仮定し，弾性スティフネスおよび密度を表 7 に示す (Ledbetter, 1981). なお二次元解析では, 4.1 節で超音波 伝搬挙動を観察した垂直断面および水平断面に対応する 2 断面を解析領域とし，オイラー角を用いた座標変換後 の弾性スティフネスのうち, 平面ひずみ近似の計算において必要となる成分の夕を抽出して解析を行った.また, ボクセルベースの有限要素法では, 散乱体あるいは外側境界が曲線形状をしている場合においても, 階段状にし か近似できないという久点があるため, 出来るだけ要素サイズを小さく設定することでこの問題を回避する必要 がある．しかしながら，要素サイズを小さくし過ぎると計算機のメモリが不足し，また計算時間も長くなってし 


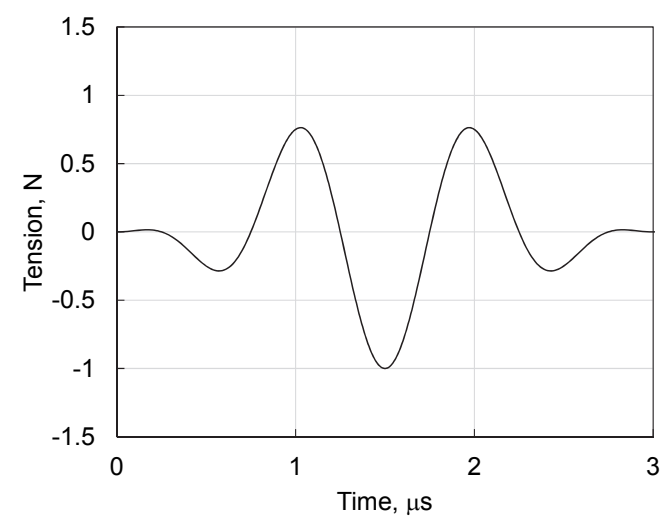

Table 7 Elastic stiffnesses and density used in wave propagation analysis.

\begin{tabular}{cccc}
\hline \multicolumn{3}{c}{ Elastic stiffnesses } & Density \\
$\mathrm{C}_{11}$ & $\mathrm{C}_{12}$ & $\mathrm{C}_{44}$ & \\
\hline $191.2 \mathrm{GPa}$ & $117.9 \mathrm{GPa}$ & $138.6 \mathrm{GPa}$ & $7,958 \mathrm{~kg} / \mathrm{m}^{3}$ \\
\hline
\end{tabular}

Fig. 12 Incident wave-form.

まう。これらの問題については, 既往研究（中畑他，2010）において検証されており，同研究を参考にして，本 研究では表 7 に示寸弾性スティフネス $C_{12}$ から得られる音速に対応寸る波長の $1 / 10$ 程度の有限要素サイズとし, 一辺 $0.25 \mathrm{~mm}$ の有限要素で解析領域を分割した. 二次元解析における垂直断面および水平断面の要素数はそれぞ れ 216,000 および 288,000 である. また，三次元解析では，解析対象として図 10 および 11 に示寸試験体を一辺 $0.25 \mathrm{~mm}$ の有限要素で分割し, 要素数はそれぞれ $34,560,000$ および $23,040,000$ とした. 時間ステップ $\Delta t$ は, $0.02 \mu$ 秒とした.

\section{$4 \cdot 3$ 超音波伝搬挙動の比較}

超音波の伝搬挙動について，4.1 節で観察した可視化結果，および 4.2 節で解析した二次元および三次元シミュ レーション結果を図 13〜16 に示す. 図 13 および 14 は図 10 に示寸垂直断面に, 図 15 および 16 は図 11 に示す水 平断面に対応する結果を示している. また, 図 13〜16における一点鎖線は振動子の中心直下の位置を示しており， 等方性均質材料では一点鎖線上で振幅が最大となるように波は伝搬する. しかしながら, 図 13〜16 の可視化実験 結果を見ると，先頭波面における振幅が最大となる位置は必ずしも一点鎖線上になく，音響異方性により波が屈 曲している様子が観察できる. また, 先頭波面の形状も, 図 15 および 16 で複雑な形状を描いている. さらに, 先頭波面より後ろでは強い散乱波が見られる．また，垂直断面に関しては図 13 および 14 が，水平断面に関して は図 15 および 16 が示すように，同じ断面においても超音波の入射位置により異なる伝搬挙動を示すことがわか る. 図 13 には, 三次元シミュレーション結果として, 変位の絶対值, 面内変位および面外変位を示している. 同 図から, 面外変位の結果は面内変位の結果と比較寸ると振幅が小さく, 特に先頭波面の振幅が小さいことがわか る. 一方で面内変位の結果は先頭波面だけでなく, 先頭波面より後ろで見られる散乱波の振幅も強い，前述した ように可視化結果は面外変位だけでなく面内変位も含んだ波形を示していると考えられるが，図 9 に示した超音 波可視化システムでは，どれくらいの割合で面内変位と面外変位が取得されているのかを定量的に示寸ことは困 難である. しかしながら，本論文では超音波の伝搬挙動を定性的に再現できているかどうかを確認することを目 的としているので, 以後, 三次元シミュレーション結果としては, 面内変位と面外変位の両方の影響を考慮でき る変位の絶対值を示すこととする. 以下では, 波の屈曲と先頭波面の形状, および先頭波面より後ろの散乱波に ついて，二次元および三次元シミュレーション結果の比較を通じて考察する.

超音波の屈曲については，まず二次元解析結果見ると，図 13 および 14 の先頭波面の屈曲は可視化実験結果と 同じくそれぞれ一点鎖線の左側および中心に見られ, 実駼結果と一致しているが, 図 15 の先頭波面は先頭波面が 二つに分かれており，実験結果と一致していない，また，図 16 の先頭波面は実験結果よりも右側に見られる. 3.3 節で述べた通り，水平断面は垂直断面と比較すると結晶粒分布の模擬が十分ではない. したがって，水平断面に 対応する図 15 および 16 の二次元解析の結果が実験結果と一致しない原因としては, CAFE 法により予測した凝 固組織が実際の組織と完全に一致していないことによると考えられる. 一方, 三次元解析結果を見ると, 図 13 (a) および(b)の先頭波面の屈曲が，実験結果と同じくそれぞれ一点鎖線の左側および中心に見られ，図 15 の結果も 
先頭波面の分岐が見られなくなり，二次元解析結果と比較すると可視化実験結果に近づいている．また，図 16 の結果も先頭波面の位置が二次元解析結果と比較すると実験結果に近づいている. 先頭波面の形状については, 二次元解析では図 13 および 14 でよく一致しているが，図 15 および 16 はあまり一致していない，一方で三次元 解析では，図 16 はあまり一致していないが，図 13〜15 で実験結果とよく一致しており，二次元結果と比較する と可視化実験結果に近づいている. これらの結果から, 波の屈曲や波面形状には, 三次元的なの結晶粒分布も大 きく影響していることがわかる.

つぎに先頭波面より後ろの散乱波については，二次元解析では全く再現できていないが，三次元解析では再現 できている.この結果より，散乱波は面外方向に分布した結晶粒からの粒界散乱や，面外方向の試験体境界から の反射波によるものと考えられる. また, 散乱波だけに着目寸ると, 面外方向が垂直断面に対応する図 15 および 16 に示した結果の方が図 13 および 14 よりも実験結果をよく再現できている. これは, 水平断面より垂直断面の 方が結晶粒分布をよく模擬できているためと考えられる.

以上より, 実際の超音波伝搬挙動を再現するためには二次元解析だけでは不十分で, 結晶粒の三次元的な分布 が考慮できる三次元解析が必要であることがわかる，今後は，鋳造過程における温度履歴の取得および核生成頻 度関数のパラメーターの最適化により, CAFE 法による凝固組織の予測精度を高め, さらに探触子のモデル化の 精度を高めることで, 実験結果により近い超音波伝搬シミュレーションを実施する予定である. これにより凝固 組織による超音波の定量的な減衰挙動の再現を目指し，最終的には，ステンレス鋳鋼の凝固組織に応じた探傷条 件の最適化に資する.

\section{5. 結 言}

本研究では, CAFE 法により静鋳造ステンレス鋼の凝固組織の三次元的な分布を予測し，予測した凝固組織を ボクセルベースの陽解法有限要素法に基づいて, 二次元および三次元超音波伝搬解析を実施した。 その結果を評 価するため, 静鋳造ステンレス鋼試験体を製作し，その断面のマクロ凝固組織をCAFE 法により予測した組織と 比較した. また, 超音波伝搬解析の結果を対応する試験体断面における超音波伝搬挙動の観察結果と比較した. 得られた結果は以下のように要約できる.

（1）凝固組織の比較では，CAFE 法により鋳型下面および側面から上面に向かって柱状晶が成長している様相を 模擬できた. また, 結晶粒面積の統計的な比較では, 垂直断面に関してはCAFE 法により得られた組織とマ クロ組織観察結果がよく一致したが，水平断面に関しては一致しなかった。これは CAFE 解析が実現象を完 全に模擬していないことが原因と考えられる. 特に, マクロスケールの有限要素法解析により得られた温度 分布が実際と異なっている可能性, およびメゾスケールのセルラーオートマトン法解析における核生成頻度 関数のパラメーター設定が適切でない可能性の二つが考えられ, これらを解決することで凝固組織の予測精 度を向上させることが可能と考えられる.

（2）超音波伝搬挙動の比較では, 垂直断面に関しては, 有限要素法に基づく二次元および三次元解析により音響 異方性による超音波の屈曲を定性的に再現できていた．また，水平断面に関しては，二次元解析結果よりも 三次元解析結果の方が実験結果に近づいていた. 一方で, 先頭波面より後ろに観察される散乱波は, 二次元 解析の結果では再現できなかったことから，面外方向に分布する結晶粒からの粒界散乱および面外方向の試 験体境界からの反射波によるものと考えられる.これら結果より, 静鋳造ステンレス鋼の凝固組織に応じた 超音波伝搬挙動を定性的に再現寸るためには三次元解析を行う必要があることがわかった. 

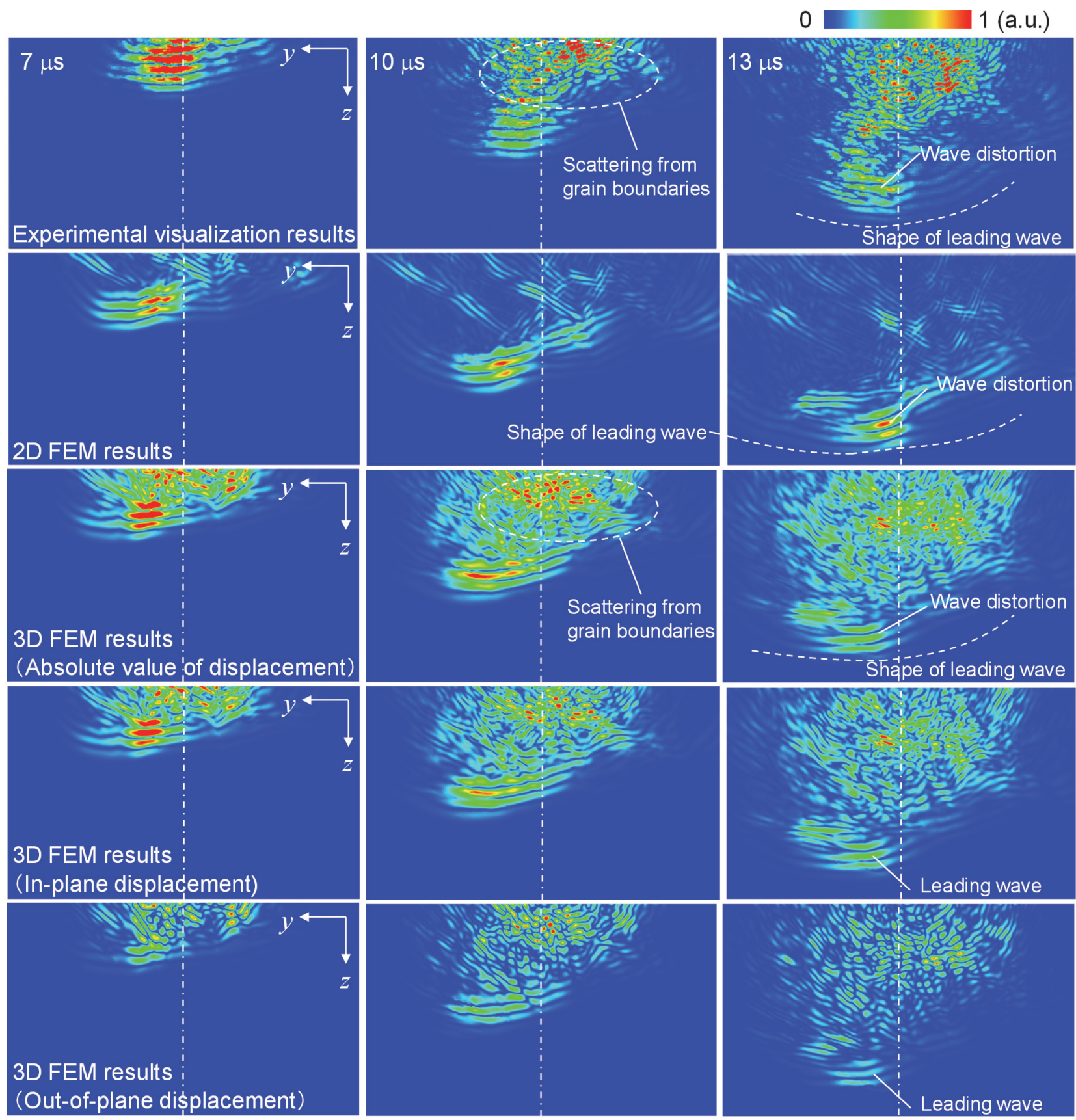

Fig. 13 Comparison of ultrasonic wave propagation behavior between experimental visualization results and FEM results. (Incident position 1, Vertical cross-section)

Amplitude of leading wave of the result for out-of-plane displacement is smaller than that for in-plane displacement. Multiple scattering from grain boundaries can be modelled in three-dimensional wave propagation simulation. Furthermore, Shapes of leading waves in simulations are in a good agreement with experimental visualization results. 

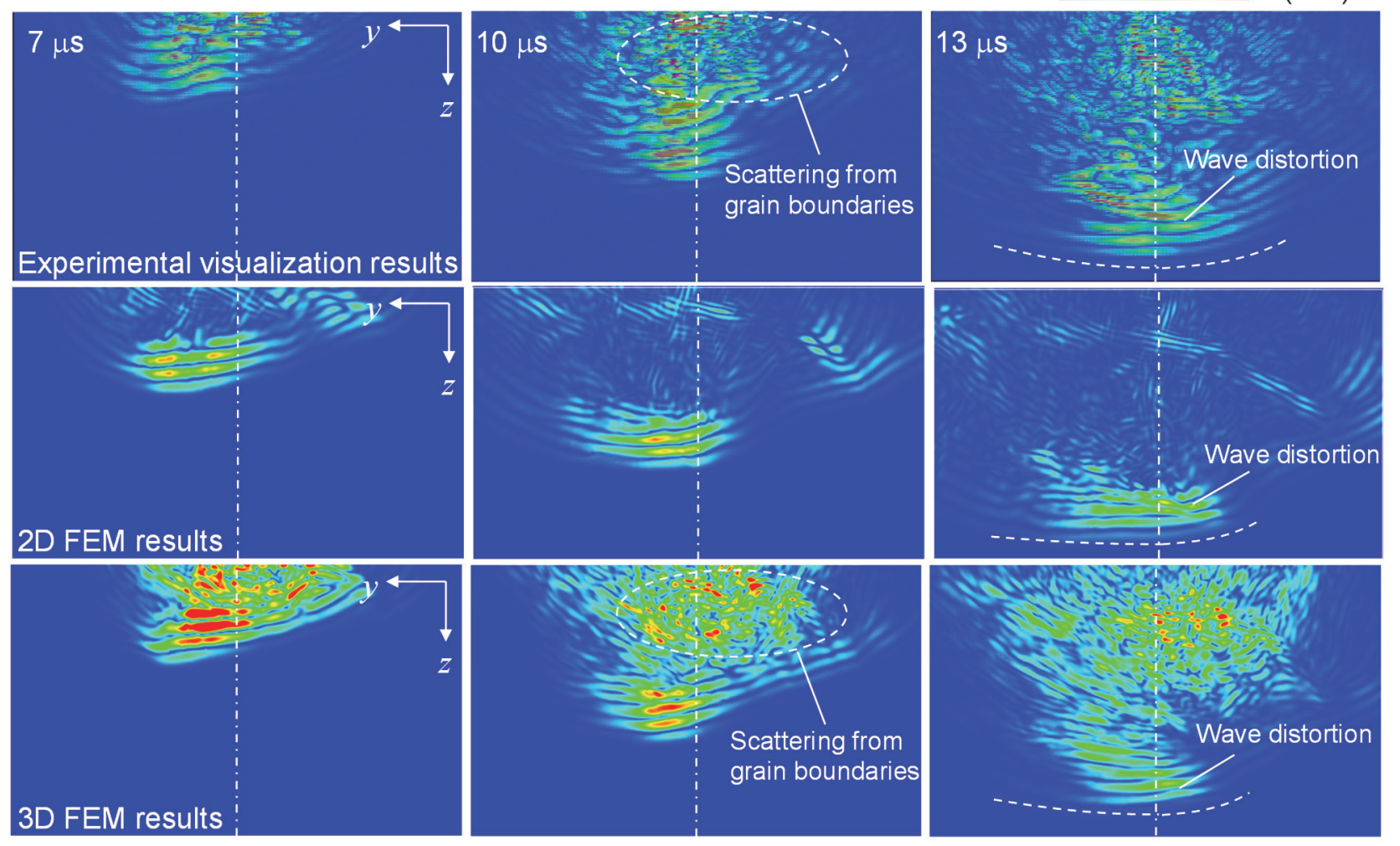

Fig. 14 Comparison of ultrasonic wave propagation behavior between experimental visualization results and FEM results.

(Incident position 2, Vertical cross-section)

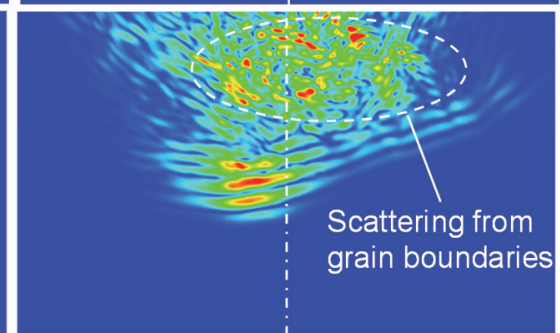

\section{0 (a.u.)}
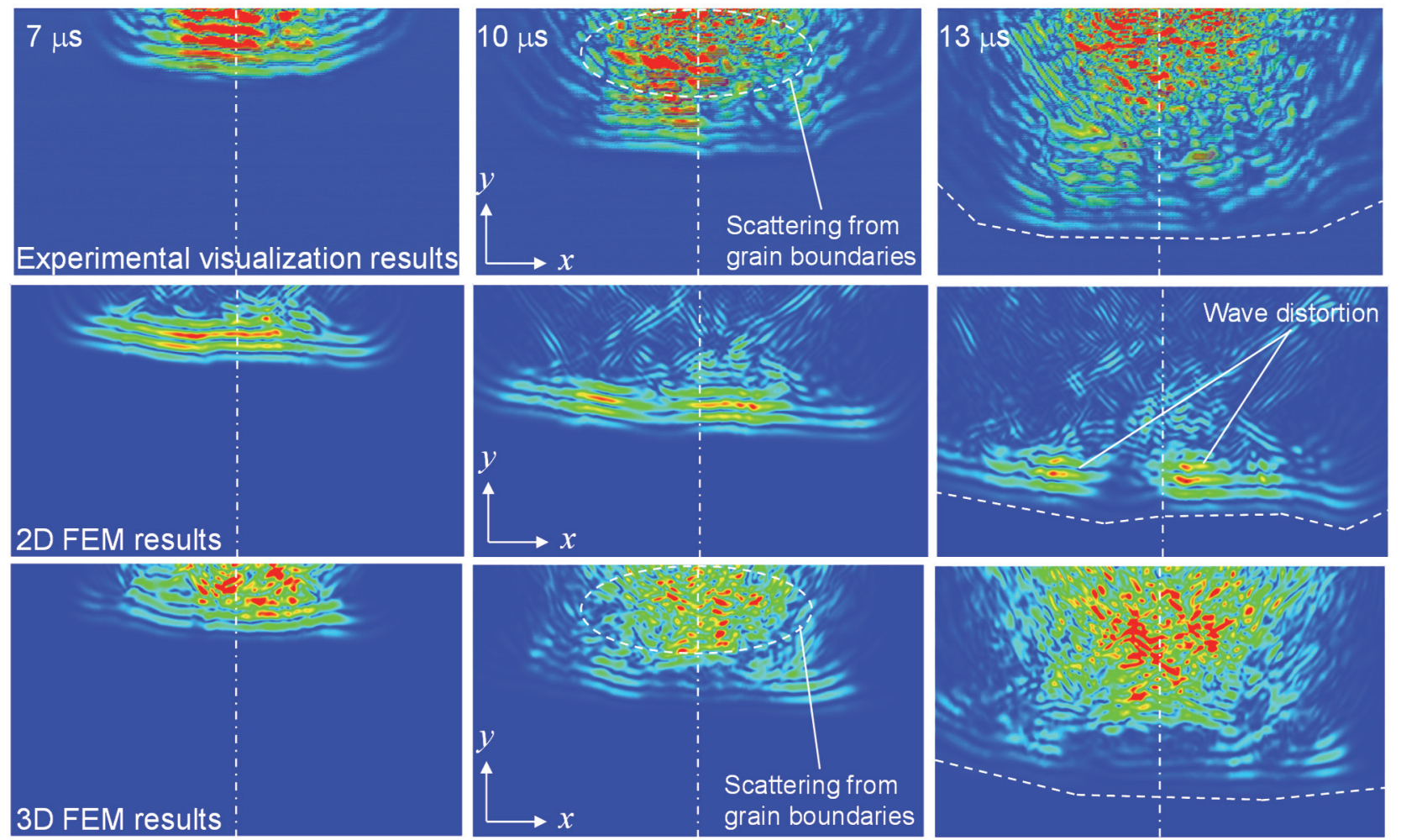

Fig. 15 Comparison of ultrasonic wave propagation behavior between experimental visualization results and FEM results. (Incident position 3, Horizontal cross-section) 

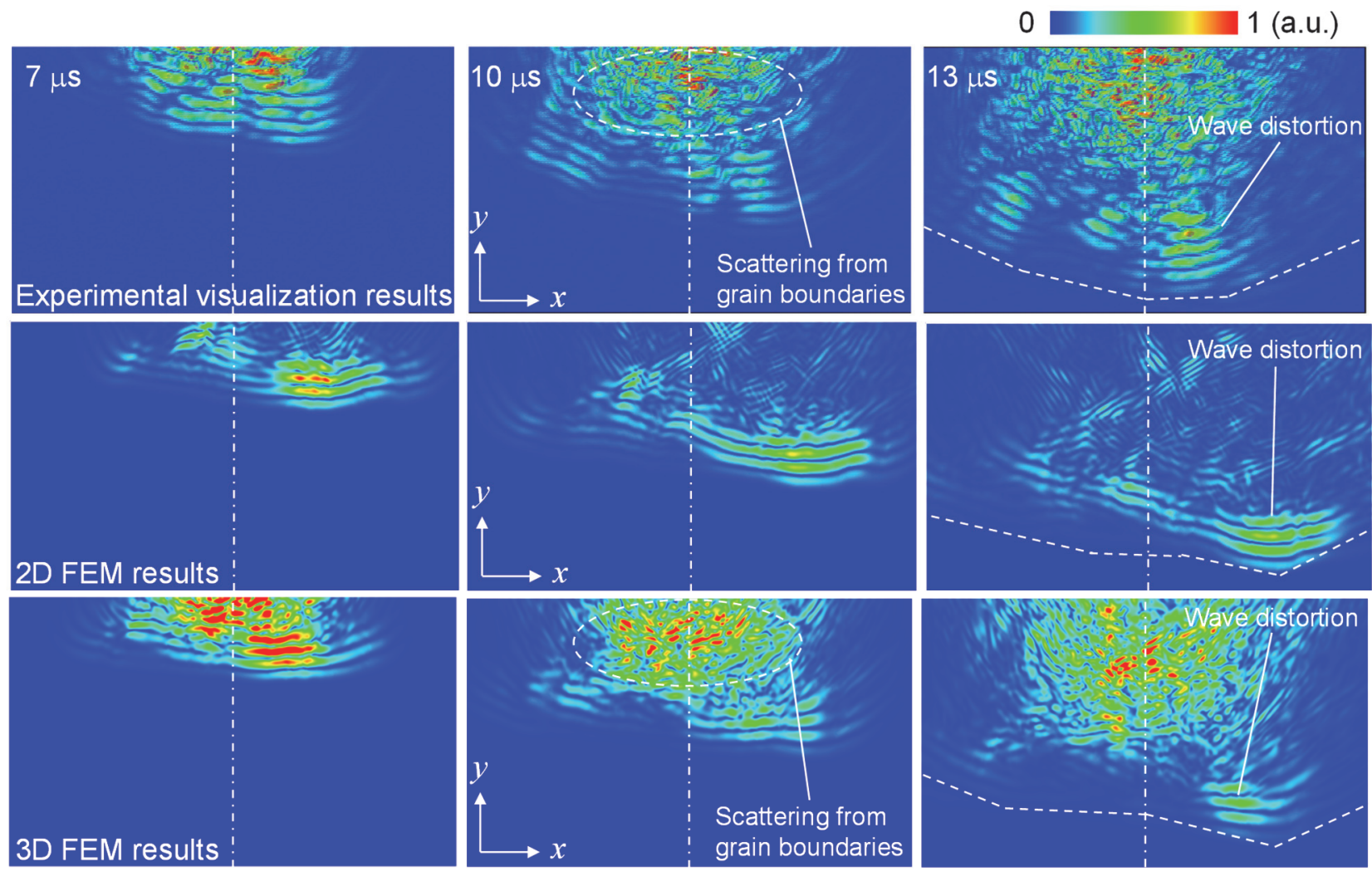

Fig. 16 Comparison of ultrasonic wave propagation behavior between experimental visualization results and FEM results.

(Incident position 4, Horizontal cross-section)

文献

Achenbach, J. D., Gautesen, A. K. and McMaken, H., Ray methods for waves in elastic solids, With applications to scattering by cracks, Pitman Advanced Publishing Program (1982).

Cao, W., Chen, S. L., Zhang, F., Wu, K., Yang, Y., Chang, Y. A., Schmid-Fetzer, R. and Oate, W. A., PANDAT software with PanEngine, PanOptimizer and PanPrecitation for multi-component phase diagram calculation and materials property simulation, CALPHAD: Computer Coupling of Phase Diagrams and Thermochmistry, Vol. 33 (2009), pp. 328-342.

Gandin, C. A. and Rappaz, M., A couple finite element-cellular automaton model for the prediction of dendritic grain structures in solidification processes, Acta Metallurgica et Materialia, Vol. 42 (1994), pp. 2233-2246.

Gandin, C. A., Desbiolles, J. L., Rappaz, M. and Thevoz, Ph., A three-dimensional cellular automaton - finite element model for the prediction of solidification grain structures, Metallurgical and Materials Transactions A: Physical Metallurgy and Materials Science, Vol. 30 (1999), pp. 3153-3165.

Gardahaut, A., Lourme, H., Jenson, F., Lin, S. and Nagai, M., Application of a 3D ray tracing model to the study of ultrasonic wave propagation in dissimilar metal welds, Proceedings of the 11th International Conference on Non Destructive Evaluation in Relation to Structural Integrity for Nuclear and Pressurized Components (11th ICNDE) (2015), WED_3_B_2.

Jenson, F., Ganjehi, L., Poidevin, C., Cattiaux, G. and Sollier, T., Modelling of ultrasonic propagation in cast stainless steels with coarse grained structures, Proceedings of the 7th International Conference on Non Destructive Evaluation in Relation to Structural Integrity for Nuclear and Pressurized Components (7th ICNDE) (2009), pp. 336-344.

黒住保夫，石田仁志，新開発自動超音波探傷システムを用いた鋳造ステンレス鋼中の欠陥検出感度およびサイジ ング特性, INSS Journal, Vol. 11 (2004), pp. 182-197.

Kurz, W., Giovanola, B. and Trivedi, R., Theory of microstructural development during rapid solidification, Acta Metallurgica et Materialia, Vol. 34 (1986), pp. 823-830.

Ledbetter, H. M., Predicted single-crystal elastic constants of stainless-steel 316, British Journal of Non-Destructive Testing, Vol. 23 (1981), pp. 286-287. 
Lin, S. and Shohji, H., Effect of refraction angle on detectability of flaws in centrifugally cast stainless steel inspected by ultrasonic phased array technology, Proceedings of the 12th International Conference on Non Destructive Evaluation in Relation to Structural Integrity for Nuclear and Pressurized Components (12th ICNDE) (2016).

林山，福富広幸，緒方隆志，超音波探傷試験における新しいき裂深さ測定法の開発（第 1 報，き裂周辺における 超音波の伝搬挙動の観測)，日本機械学会論文集 A 編，Vol. 73, No. 728 (2007), pp. 449-454.

林山，東海林一，遠心鋳造ステンレス鋼に対するフェーズドアレイ超音波法の開発一第 1 報 : 異方性を考慮した 遅延時間の計算方法の提案一，電力中央研究所報告，Q17002 (2018).

Moelans, N., Blanpain, B. and Wollants, P., An introduction to phase-field modeling of microstructure evolution, Computer Coupling of Phase Diagrams and Thermochemistry, Vol. 32 (2008), pp. 268-294.

Nageswaran, C., Carpentier, C. and Tse, Y. Y., Microstructural quantification, modelling and array ultrasonics to improve the inspection of austenitic welds, Insight, Vol. 51 (2009), pp. 1-7.

Nakahata, K., Sugahara, H., Barth, M., Kohler, B. and Schubert, F., Three dimensional image-based simulation of ultrasonic wave propagation pin polycrystalline metal using phase-field modeling, Ultrasonics, Vol. 67 (2016), pp. 18-29.

中畑和之, 徳永淳一, 廣瀬壮一, イメージベース波動伝搬シミュレーションと超音波探傷法のモデル化への応用, 非破壊検査, Vol. 59 (2010), pp. 231-238.

Natsume, Y. and Ohsasa, K., Prediction of casting structure in aluminum-base multi-component alloys using heterogeneous nucleation parameter, ISIJ International, Vol. 46, No. 6 (2006), pp. 896-902.

野上敦嗣, 小関敏彦, 福田由佳, 八イブリッドモデルと計算熱力学連成による凝固組織シミュレーション, まて りあ, Vol. 42 (2003), pp. 731-737.

Sakamoto, K., Furukawa, T., Komura, I., Kamiyama, Y. and Mihara, T., Research on ultrasonic inspection of cast austenitic stainless steel piping, Proceedings of the ASME Pressure Vessels \& Piping Conference (2012), Paper No. PVP2012-78051.

Spittle, J. A. and Brown, S. G. R., Computer simulation of the effects of alloy variables on the grain structures of castings, Acta Metallurgica, Vol. 37 (1989), pp. 1803-1810.

Steinbach, I., Phase-field models in materials science, Modeling and Simulation in Materials Science and Engineering, Vol. 17 (2009), 073001.

日本機械学会，発電用原子力規格維持規格 (2012 年度版), JSME S-NA1-2012 (2012).

米澤岡川, 三次元有限要素法鋳造シミュレーションソフトウェア ProCAST, 鋳造工学, Vol. 86 (2014), pp. 940-945.

Zhu, P. and Smith, R. W., Dynamic simulation of crystal growth by monte carlo method-II. Ingot microstructures, Acta Metallurgica et Materialia, Vol. 40 (1992), pp. 3369-3379.

\section{References}

Achenbach, J. D., Gautesen, A. K. and McMaken, H., Ray methods for waves in elastic solids, With applications to scattering by cracks, Pitman Advanced Publishing Program (1982).

Cao, W., Chen, S. L., Zhang, F., Wu, K., Yang, Y., Chang, Y. A., Schmid-Fetzer, R. and Oate, W. A., PANDAT software with PanEngine, PanOptimizer and PanPrecitation for multi-component phase diagram calculation and materials property simulation, CALPHAD: Computer Coupling of Phase Diagrams and Thermochmistry, Vol. 33 (2009), pp. 328-342.

Gandin, C. A. and Rappaz, M., A couple finite element-cellular automaton model for the prediction of dendritic grain structures in solidification processes, Acta Metallurgica et Materialia, Vol. 42 (1994), pp. 2233-2246.

Gandin, C. A., Desbiolles, J. L., Rappaz, M. and Thevoz, Ph., A three-dimensional cellular automaton - finite element model for the prediction of solidification grain structures, Metallurgical and Materials Transactions A: Physical Metallurgy and Materials Science, Vol. 30 (1999), pp. 3153-3165.

Gardahaut, A., Lourme, H., Jenson, F., Lin, S. and Nagai, M., Application of a 3D ray tracing model to the study of ultrasonic wave propagation in dissimilar metal welds, Proceedings of the 11th International Conference on Non Destructive Evaluation in Relation to Structural Integrity for Nuclear and Pressurized Components (11th ICNDE) (2015), WED_3_B_2.

Jenson, F., Ganjehi, L., Poidevin, C., Cattiaux, G. and Sollier, T., Modelling of ultrasonic propagation in cast stainless steels with coarse grained structures, Proceedings of the 7th International Conference on Non Destructive Evaluation in Relation to Structural Integrity for Nuclear and Pressurized Components (7th ICNDE) (2009), pp. 336-344.

Kurozumi, Y. and Ishida, H., Detection sensitivity and sizing ability of defects in cast stainless steel with newly developed 
automatic ultrasonic inspection system, INSS Journal, Vol. 11 (2004), pp. 182-197 (in Japanese).

Kurz, W., Giovanola, B. and Trivedi, R., Theory of microstructural development during rapid solidification, Acta Metallurgica et Materialia, Vol. 34 (1986), pp. 823-830.

Ledbetter, H. M., Predicted single-crystal elastic constants of stainless-steel 316, British Journal of Non-Destructive Testing, Vol. 23 (1981), pp. 286-287.

Lin, S. and Shohji, H., Effect of refraction angle on detectability of flaws in centrifugally cast stainless steel inspected by ultrasonic phased array technology, Proceedings of the 12th International Conference on Non Destructive Evaluation in Relation to Structural Integrity for Nuclear and Pressurized Components (12th ICNDE) (2016).

Lin, S., Fukutomi, H. and Ogata, T., Development of new flaw depth sizing technique in ultrasonic testing (1st report, Observation of wave propagation behavior around cracks), Transactions of the Japan Society of Mechanical Engineers, Series A, Vol. 73, No. 728 (2007), pp. 449-454 (in Japanese).

Lin, S. and Shoji, H., Development of phased array ultrasonic techniques for centrifugally cast stainless steel - Part 1 : Proposal of computation method for delay law taking anisotropy in consideration -, Q17002 (2018) (in Japanese).

Moelans, N., Blanpain, B. and Wollants, P., An introduction to phase-field modeling of microstructure evolution, Computer Coupling of Phase Diagrams and Thermochemistry, Vol. 32 (2008), pp. 268-294.

Nageswaran, C., Carpentier, C. and Tse, Y. Y., Microstructural quantification, modelling and array ultrasonics to improve the inspection of austenitic welds, Insight, Vol. 51 (2009), pp. 1-7.

Nakahata, K., Sugahara, H., Barth, M., Kohler, B. and Schubert, F., Three dimensional image-based simulation of ultrasonic wave propagation pin polycrystalline metal using phase-field modeling, Ultrasonics, Vol. 67 (2016), pp. 18-29.

Nakahata, K., Tokunaga, J. and Hirose, S., Image-based simulation of wave propagation and its application to UT modelings, Journal of JSNDI, Vol. 59 (2010), pp. 231-238 (in Japanese).

Natsume, Y. and Ohsasa, K., Prediction of casting structure in aluminum-base multi-component alloys using heterogeneous nucleation parameter, ISIJ International, Vol. 46, No. 6 (2006), pp. 896-902.

Nogami, A., Koseki, T. and Fukuda Y., Simulation of solidification morphology using monte carlo and finite difference hybrid modeling incorporated with computational thermodynamics, Materia Japan, Vol. 42 (2003), pp. $731-737$ (in Japanaese).

Sakamoto, K., Furukawa, T., Komura, I., Kamiyama, Y. and Mihara, T., Research on ultrasonic inspection of cast austenitic stainless steel piping, Proceedings of the ASME Pressure Vessels \& Piping Conference (2012), Paper No. PVP2012-78051.

Spittle, J. A. and Brown, S. G. R., Computer simulation of the effects of alloy variables on the grain structures of castings, Acta Metallurgica, Vol. 37 (1989), pp. 1803-1810.

Steinbach, I., Phase-field models in materials science, Modeling and Simulation in Materials Science and Engineering, Vol. 17 (2009), 073001.

The Japan Society of Mechanical Engineers, Codes for Nuclear Power Generation Facilities, Rules on Fitness-for-Service for Nuclear Power Plants, JSME S NA1-2012 (2012) (in Japanese).

Yonezawa, T., Recent trend of casting simulation system ProCAST, Journal of Japan Foundry Engineering Society, Vol. 86 (2014), pp. 940-945 (in Japanese).

Zhu, P. and Smith, R. W., Dynamic simulation of crystal growth by monte carlo method-II. Ingot microstructures, Acta Metallurgica et Materialia, Vol. 40 (1992), pp. 3369-3379. 